This PDF is a selection from a published volume from the National Bureau of Economic Research

Volume Title: NBER International Seminar on Macroeconomics 2008

Volume Author/Editor: Jeffrey Frankel and Christopher Pissarides

Volume Publisher: University of Chicago Press

Volume ISBN: 978-0-226-10732-5

Volume URL: http://www.nber.org/books/fran08-1

Conference Date: June 20-21, 2008

Publication Date: April 2009

Title: Capital Flow Bonanzas: An Encompassing View of the Past and Present Author: Carmen Reinhart, Vincent Reinhart

URL: http://www.nber.org/chapters/c8229

Chapter pages in book: $(9-62)$ 


\title{
Capital Flow Bonanzas: An Encompassing View of the Past and Present
}

\author{
Carmen M. Reinhart, University of Maryland and NBER \\ Vincent R. Reinhart, American Enterprise Institute
}

\section{Introduction}

A pattern has often been repeated in the modern era of global finance. Foreign investors turn with interest toward some developing country. Capital flows in volume into small and shallow local financial markets. The exchange rate tends to appreciate, asset prices to rally, and local commodity prices to boom. These favorable asset price movements improve national fiscal indicators and encourage domestic credit expansion. These, in turn, exacerbate structural weaknesses in the domestic banking sector even as those local institutions are courted by global financial institutions seeking entry into a hot market. At the same time, local authorities resort to large-scale foreign exchange sales of the local currency to cushion the effects on the exchange rate of the capital inflow bonanza.

Other policy interventions, such as increases in reserve requirements and transactions taxes, usually follow to insulate the domestic economy from the accumulation of reserves. An inherent tension emerges: Local authorities take such changes as a global vote of approval that might encourage them to delay the difficult task of structural adjustment.

This pattern is etched sharply in the experience of the exchange rate mechanism, the exchange rate mechanism squared, and the Latin convergence associated with the North American Free Trade Agreement and its regional successors. In the run-up to a more perfect union, potential entrants are increasingly looked on favorably by global investors. Those investors appreciate that close integration with a strong anchor country or group of countries will ultimately discipline policy makers in the periphery, which will narrow exchange rate fluctuations and country risk spreads and buoy local equity prices. But these same dynamics also play out in commodity-exporting emerging market economies when the prices of their output surge on world markets or 
when very low interest rates and sluggish growth in the advanced countries turn the attention of investors there outward. Across countries, a different rising tide raises all boats.

But tides also go out when the fancy of global investors shifts and the "new paradigm" looks shopworn. Flows reverse and asset prices give back their gains, often forcing a painful adjustment on the economy.

This experience has provided a fertile testing ground for international economists. A varied flora has blossomed that will be reviewed in Section II. Given double-entry bookkeeping and the zero-sum nature of global trade, these issues of global adjustment have been described in terms of the current or financial accounts and as deterioration in some countries or improvement in others. Moreover, the time windows have been chosen to isolate the buildup or rundown of any of these measures.

This paper attempts to be encompassing in its examination of these issues by simplifying the definition of the key event that is studied and by widening the time window around that event. We investigate what happens before, during, and after a capital flow bonanza. That is, we ask, how do economies perform in and around periods when capital inflows are relatively large (or, equivalently, when their financial account surpluses are relatively large)? Owing to data limitations discussed below, we make this operational by examining episodes of large current account deficits.

We study 181 countries from 1980 to 2007, a subset of 66 countries from 1960 to 2007 for which more detailed information on economic variables is available, and a smaller group of 18 countries for which house price data are available; the samples include all regions and income groups. Our primary aim is to quantitatively define and date capital inflow bonanza episodes so as to study their various aspects. In Section III, we document several features of these bonanza periods, including their incidence and duration. In Section IV, we examine the evidence on potential links between capital flow bonanzas and debt, currency, inflation, and banking crises. In Section V, we systematically illustrate the behavior of a variety of macroeconomic, financial, and policy indicators on the eve and aftermath of these episodes.

Our main findings can be summarized as follows: With nearly 50 years of data, it is evident that bonanzas have become more frequent as restrictions on international capital flows have been relaxed worldwide. Although the approaches differ, this finding is in line with the evidence presented in Eichengreen and Adalet (2005).

The heavy inflow episode can persist, often lulling policy makers and investors into treating the bonanza as a permanent phenomenon rather than a temporary shock. Episodes end, more often than not, with an 
abrupt reversal or "sudden stop" à la Calvo (as in Calvo [1998]). The current account path around bonanzas is distinctly V-shaped, irrespective of whether the broader, but more recent, sample or the less inclusive, but longer, sample is the benchmark.

Capital inflow bonanza periods are associated with a higher incidence of banking, currency, and inflation crises in all but the high-income countries (using some of the crises indicators developed in Kaminsky and Reinhart [1999] and codified in Reinhart and Rogoff [2008b]). This result is not the artifact of a few extreme cases; in more than $60 \%$ of the countries, the probability of a crisis around the dates of a capital flow bonanza is higher than for the entire sample. Capital flow bonanzas systematically precede sovereign default episodes.

In developing countries (those designated by the World Bank as middle and low income), the stance of fiscal policy, as measured by the growth in real government spending, is notoriously procyclical during capital inflow bonanzas. This is consistent with the earlier observation that temporary "good times" are often treated as permanent. In effect, our preliminary results also suggest that fiscal policy plays a destabilizing role around capital flow bonanzas-and possibly more generally.

For the advanced economies, the results are not as stark, since there is no systematic cross-country evidence over 1960-2007 that the probability of a financial crisis increases during bouts of heavy capital inflows. The crisis-prone Nordic countries in the early 1990s and the Icelandic, U.K., and U.S. crises at present would appear to be important departures from this general result (as in Reinhart and Rogoff [2008a]). Nonetheless, capital flow bonanzas are associated with more volatile macroeconomic outcomes for real GDP growth, inflation, and the external accounts.

Real GDP growth tends to be higher in the run-up to a bonanza and then systematically lower. The imprint of bonanzas is evident in asset markets. Equity prices rise when capital flows in and retreat when capital flows out. A similar pattern is evident in house prices for our small sample. A bonanza is not to be confused with a blessing.

The last section (Sec. VI) turns to some of the policy implications of our analysis and discusses possible future research in this area.

\section{Concepts and Data Issues}

\section{A. Reviewing the Existing Literature}

The existing literature has studied multiple manifestations of international adjustment in the balance-of-payments data. Double-entry bookkeeping 
and the global summing to zero of trade flows produce the four alternative frames of reference laid out in table 1 . The main issues of adjustment can be described in terms of either an improvement or a deterioration (along the rows of the matrix) in either the current or capital accounts (along the columns).

There is a rich empirical literature on current account reversals, the upper-left cell mostly documenting the macroeconomic consequences of a marked improvement in a sample of many countries. Many features of these studies follow the path laid out in the pioneering paper by MilesiFerretti and Razin (2000). As summarized in table 2, they established three criteria to identify a current account reversal that are now the norm: The change in the balance must be large relative to nominal GDP, must be large absolutely in dollar terms, and must not be the product of a spike in a single year. Focusing on low- and middle-income countries, they find that the adjustment experience is heterogeneous and depends importantly on whether the currency crashes on the foreign exchange market.

Eichengreen and Adalet (2005) extended the sample to include the pre-1970 experience, thereby providing historical context. In particular, large current account reversals appear to be the product of open trade in goods, services, and assets. Reversals have been frequent only in the two heydays of global capital markets-the recent period and the 1920s and 1930s. Large adjustments were much rarer under the pre-World War I gold standard and during the Bretton Woods years.

An important fuel to the study of current account reversals has been the U.S. experience of sustained large deficits. The intent is to find rules of thumb that will be informative about the U.S. experience when the presumed "day of reckoning" comes and the unsustainable is no longer sustained. The search for such lessons appears in important papers by Edwards $(2005,2007)$ and Freund and Warnock (2005). They find an important role for the textbook forces thought to rein in a current account imbalance-a slowing in income growth and a real depreciation of the currency.

Table 1

Frames of Reference in the Literature

\begin{tabular}{lll}
\hline & \multicolumn{2}{c}{ Balance-of-Payments } \\
\cline { 2 - 3 } Change & \multicolumn{1}{c}{ Current Account } \\
\hline Improvement & Current account reversal & \multicolumn{1}{c}{ Capital Account } \\
Deterioration & Twin deficits & Capital inflow problem \\
\hline
\end{tabular}


Similar interest in the U.S. experience produced work in the 1980s on why the current account deteriorated, which is the subject of the lowerleft cell of table 1. The main culprit at that time was identified to be the large budget deficit, which through national income accounting was mirrored in its twin, the current account. Contemporaneous discussions of this can be found in Federal Reserve Bank of Kansas City (1985), and a later review has been provided by Bosworth (1993). This line of argument petered out in the late 1990s when the U.S. federal budget went into surplus but the current account remained deeply in red.

Those researchers focusing on the right cells of the contingency table typically take the perspective of emerging market economies. In particular, they view the portfolio investment decisions of investors at the center of the global financial system as somewhat fickle. Assets in some emerging markets may be in fashion for a time. Those inflows tend to appreciate the exchange rate, lead to reserve accumulation as authorities attempt to offset that force, and push up prices in asset markets. Altogether, this presents a "capital inflow problem" as described by Calvo, Leiderman, and Reinhart (1993), an issue also studied by FernandezArias and Montiel (1996).

When capital no longer flows into an emerging market, the nation can no longer support an excess of spending over income. The result, in the phrase of Calvo and his coauthors, is a "sudden stop," forcing current account adjustment. The empirical application of this insight can be found in Calvo, Izquierdo, and Mejía (2004) and Calvo, Izquierdo, and Loo-Kung (2006), both of which are described in more detail in table 2.

\section{B. Defining a Capital Flow Bonanza}

The decision to adopt a particular algorithm to date and catalog capital inflow bonanzas naturally involves trade-offs. An advantage of casting our net wide to all large capital inflow episodes is that it does not predispose us to episodes that inevitably ended in a marked reversal. In this sense, there is a lower predisposition to tilt the analysis toward economic crises. An inflow bonanza can end with a bang or with a whimper. In this sense, our approach parallels the analysis of Goldfajn and Valdes (1999), who, rather than starting their analysis with currency crises dates, began by documenting episodes of cumulative real exchange rate appreciations of varying degrees and then sorted out which episodes unwound through an abrupt nominal exchange rate crash 
Table 2

Current and Capital Account Reversals: Some Definitions

\begin{tabular}{|c|c|}
\hline Study & Criteria Used to Select the Episodes of Interest \\
\hline $\begin{array}{l}\text { Current account reversals: } \\
\text { Milesi-Ferretti and Razin (2000); } \\
\text { also Edwards (2005), Eichengreen } \\
\text { and Adalet (2005), and Freund } \\
\text { and Warnock (2005) }\end{array}$ & $\begin{array}{l}\text { Their underlying idea is that "large" events } \\
\text { provide more information on determinants } \\
\text { of reductions in current account deficits than } \\
\text { short-run fluctuations. These events have } \\
\text { to satisfy three requirements: } \\
\text { 1. There must be an average reduction in the } \\
\text { current account deficit of at least } 3 \text { (or } 5 \text { ) } \\
\text { percentage points of GDP over a period of } \\
3 \text { years with respect to the } 3 \text { years before } \\
\text { the event. } \\
2 \text {. The maximum deficit after the reversal must } \\
\text { be no larger than the minimum deficit in the } \\
3 \text { years preceding the reversal. } \\
3 \text {. The average current account deficit must be } \\
\text { reduced by at least one-third. The first and } \\
\text { second requirements should ensure that we } \\
\text { capture only reductions of sustained current } \\
\text { account deficits rather than sharp but } \\
\text { temporary reversals. The third requirement } \\
\text { is necessary so as to avoid counting as a } \\
\text { reversal a reduction in the current account } \\
\text { deficit from, say, } 15 \% \text { to } 12 \% \text {. Events are } \\
\text { based on } 3 \text {-year averages. }\end{array}$ \\
\hline $\begin{array}{l}\text { Capital account-sudden stops: } \\
\text { Calvo, Izquierdo, and } \\
\text { Mejía (2004) }\end{array}$ & $\begin{array}{l}\text { A sudden stop is defined as a phase that meets } \\
\text { the following conditions: } \\
\text { 1. It contains at least one observation in } \\
\text { which the year-on-year fall in capital flows lies } \\
\text { at least two standard deviations below its } \\
\text { sample mean (this addresses the "unexpected" } \\
\text { requirement of a sudden stop). } \\
\text { 2. The sudden stop phase ends once the annual } \\
\text { change in capital flows exceeds one standard } \\
\text { deviation below its sample mean. This will } \\
\text { generally introduce persistence, a common } \\
\text { fact of sudden stops. } \\
\text { 3. Moreover, for the sake of symmetry, the start } \\
\text { of a sudden stop phase is determined by the } \\
\text { first time the annual change in capital flows } \\
\text { falls one standard deviation below the mean. } \\
\text { (continued) }\end{array}$ \\
\hline
\end{tabular}


Table 2

Continued

\begin{tabular}{ll}
\hline Study & Criteria Used to Select the Episodes of Interest \\
\hline Capital account-sudden stops: & 1. In addition to the criterion of large capital \\
Calvo, Izquierdo, and & flow reversals exceeding two standard \\
Loo-Kung (2006) & $\begin{array}{l}\text { deviations from the mean (for their capital } \\
\text { flow proxy), Calvo et al. have the following } \\
\text { requirement: }\end{array}$
\end{tabular}

2. These reversals must be accompanied by a spike in some external aggregate measure of the cost of funds in order to capture systemic effects. More specifically, Calvo et al. use the (log of the) J. P. Morgan Emerging Market Bond Index spread over U.S. Treasury bonds for emerging markets, the Merrill Lynch euro area Government Index spreads for euro area countries (as well as Nordic countries such as Denmark, Norway, and Sweden), and G7 Government Index spreads for all remaining developed countries. Calvo et al. construct aggregate high-spread episodes in a fashion analogous to the Calvo, Izquierdo, and Mejía (2004) measure of large capital flow reversals (i.e., Calvo et al. consider spikes in spreads exceeding two standard deviations from the mean) and determine that a sudden stop occurs when the measure of the fall-incapital-flows phase overlaps (on a yearly basis) with the aggregate high-spread phase. Episodes that lie within a 6-month interval are considered part of the same sudden stop phase.

and which did so through reductions in inflation versus their trading partners. ${ }^{1}$

We began with the presumption that the best indicator of capital flows would be reserve accumulation less the current account balance, since it measures the resources acquired (or dispersed) through issuance (or retirement) of home country liabilities. This indirect measurement of the change in liabilities seemed more likely to be available for a longer time span and for more countries than direct information from financial accounts. In the event, data on reserves tend to be published only on a delayed basis in many countries. To keep our efforts topical, the current account balance as a percentage of GDP is our benchmark indicator. It is measured more consistently across time and international boundaries than its capital account and financial account counterpart. ${ }^{2}$ For the more recent period, the same filter rules are applied to the other measures as a robustness check as is reported in the appendix. 
We began by applying the three-step approach proposed by MilesiFerretti and Razin to our data set with a suitable revision that does not enforce a current account reversal. This approach, however, raised some issues about dating the bonanzas of many well-known episodes. In some countries in which the deterioration in the current account (and hence the rise in capital inflows) was a relatively smooth process over several years, this algorithm did not flag these episodes as bonanzas even though the current account deficits were large by historical standards. Heavy inflow cases, such as the United States since 2004 and Australia in several cycles since 1960, were missed altogether. In other cases, the inflow bonanza persisted after the peak current account deficit had been reached. For instance, the Thai and Malaysian current account deficits peaked in the early 1990s; however, while the deficits remained large by historical standards well into 1996, these years are not classified as bonanzas by this algorithm. Many of the important (but less persistent) surges in capital inflows of the late 1970s and early 1980s also go undetected.

We ultimately settled on an alternative algorithm that provided uniform treatment across countries but was flexible enough to allow for significant cross-country variation in the current account. As in Kaminsky and Reinhart (1999), we select a threshold to define bonanzas that is common across countries (in this case the 20th percentile). ${ }^{3}$ This threshold included most of the better-known episodes in the literature but was not so inclusive as to label a bonanza more "routine" deteriorations in the current account. Because the underlying frequency distributions vary widely across countries, the common threshold produces quite disperse country-specific cutoffs. For instance, in the case of relatively closed India, the cutoff to define a bonanza is a current account deficit/ GDP ratio in excess of $1.8 \%$, whereas for trade-oriented Malaysia the comparable cutoff is a deficit/GDP ratio of $6.6 \%{ }^{4}$

Figure 1, which plots the frequency distribution for 181 countries, highlights these differences across both countries and major income groups. As the figure makes clear, the range of experience is wide, but large deficits appear more frequently in lower-income countries.

\section{Sample Coverage and Data}

We employ three samples to analyze the capital bonanza phenomenon. The broadest sample includes the 181 countries covered in the International Monetary Fund's World Economic Outlook for 1980-2007. Information is available on the current account, real GDP, inflation, and the real 


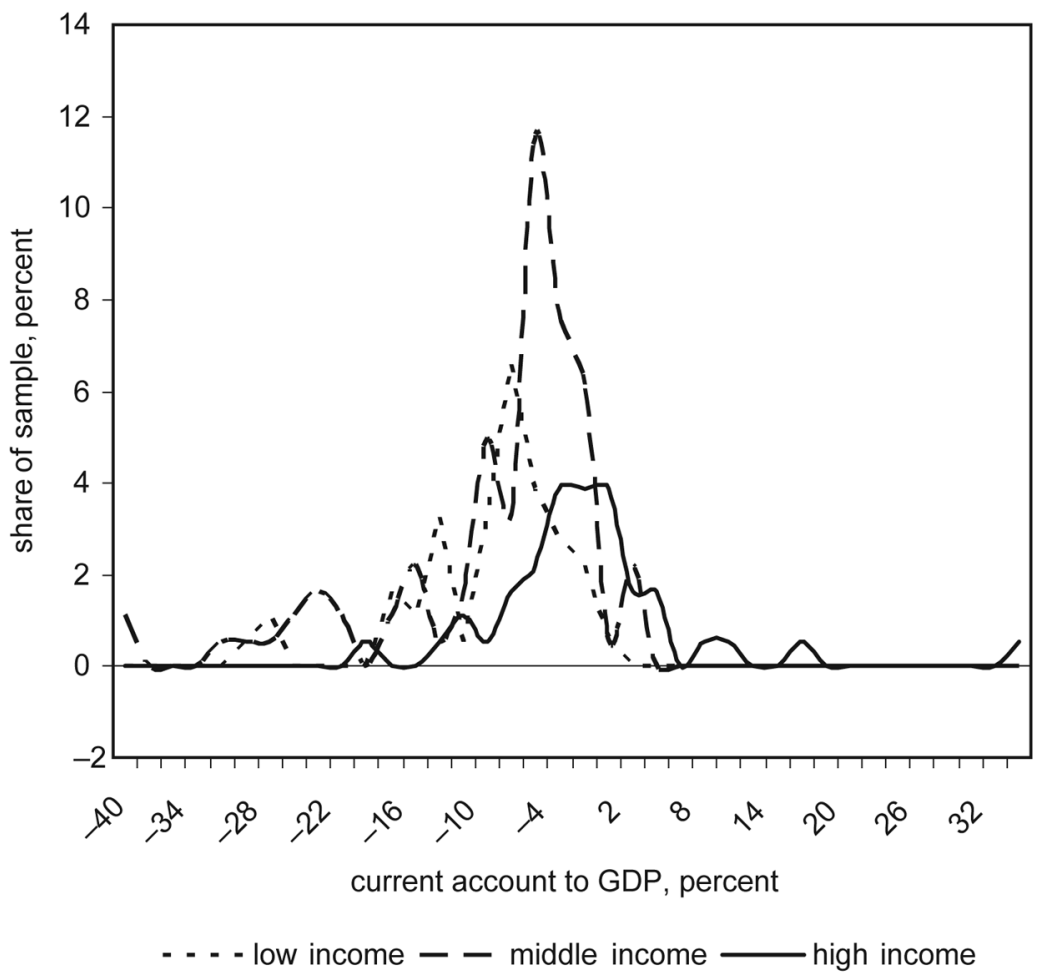

Fig. 1. Distribution of current account cutoffs, used in defining bonanzas: 181 countries, 1980-2008. Sources: International Monetary Fund, World Economic Outlook, and authors' calculations.

exchange rate. This allows us to examine the recent country experiences in a truly global setting.

We will refer to the second data set as the "core" sample, which spans 1960-2007 and covers 64 countries across all regions. This sample is dominated by high- and middle-income countries, where data availability poses less of a constraint. It is for this sample that we are able to examine in greater depth the macroeconomic features of the bonanzas. Also, for the core countries, we have a sufficiently complete dating of economic crises (debt, banking, etc.) that allows us to assess whether a capital inflow bonanza predisposes countries to financial crises.

The third set is a small sample of 18 industrial countries for which we have data on house prices from the Bank for International Settlements. Otherwise, the data coverage for this group is the same as for the core group. Appendix tables A1 and A2 list the countries (and the income group they belong to) that make up the three samples. ${ }^{5}$ 
All data are annual. In addition to including time series on the current account, capital and financial accounts, and nominal GDP (all in U.S. dollars), we employ a variety of macroeconomic time series. These include country-specific variables: international reserves, nominal and real exchange rates, real GDP, consumer prices, export, imports, government expenditure, revenue, deficits, equity, and (in the case of some advanced economies) real estate prices. In addition, we have dichotomous variables that date external debt crises, currency crashes, and inflation and banking crises. Global variables, such as commodity prices, international interest rates, growth in the world's largest economies, measures of macroeconomic volatility, and the global incidence of capital flow bonanzas and various "types" of economic crises, round out the analysis. Appendix table A3 provides a full list of the variables as well as their respective sources.

The availability of long time series on various aspects of macroeconomic performance was important in deciding on the design principle of our key indicator - a capital flow bonanza. Because we had gathered a sufficiently rich data set, we could be somewhat general in defining events, because we will be able to characterize behavior in a wide window around those events. That is, we can see the run-up and the winddown in a manner that encompasses the definitions of earlier work.

\section{Capital Flow Bonanzas: Global Cycles and Country Episodes}

In what follows, we provide a sketch of country-specific and global capital flow cycles, including incidence, by region and income group; duration; and links to global indicators.

\section{A. The Big Picture}

It is relatively well known that international capital flows have an important cyclical component. ${ }^{6}$ The fact that capital (contrary to the predictions of the neoclassical growth paradigm) does not flow from rich to poor countries has also received considerable attention. ${ }^{7}$ Both of these stylized facts are illustrated in the two panels of figure 2, which plot the incidence (i.e., the percentage of countries) of capital inflow bonanzas for the broad sample consisting of 181 countries. The specific dates of the bonanza episodes on a country-by-country basis are listed in the four-part appendix table A4, for high, middle-high, middle-low, and low-income groupings. Column 2 of this table also provides the dates of sovereign external debt crises (defaults or restructuring). ${ }^{8}$ For 


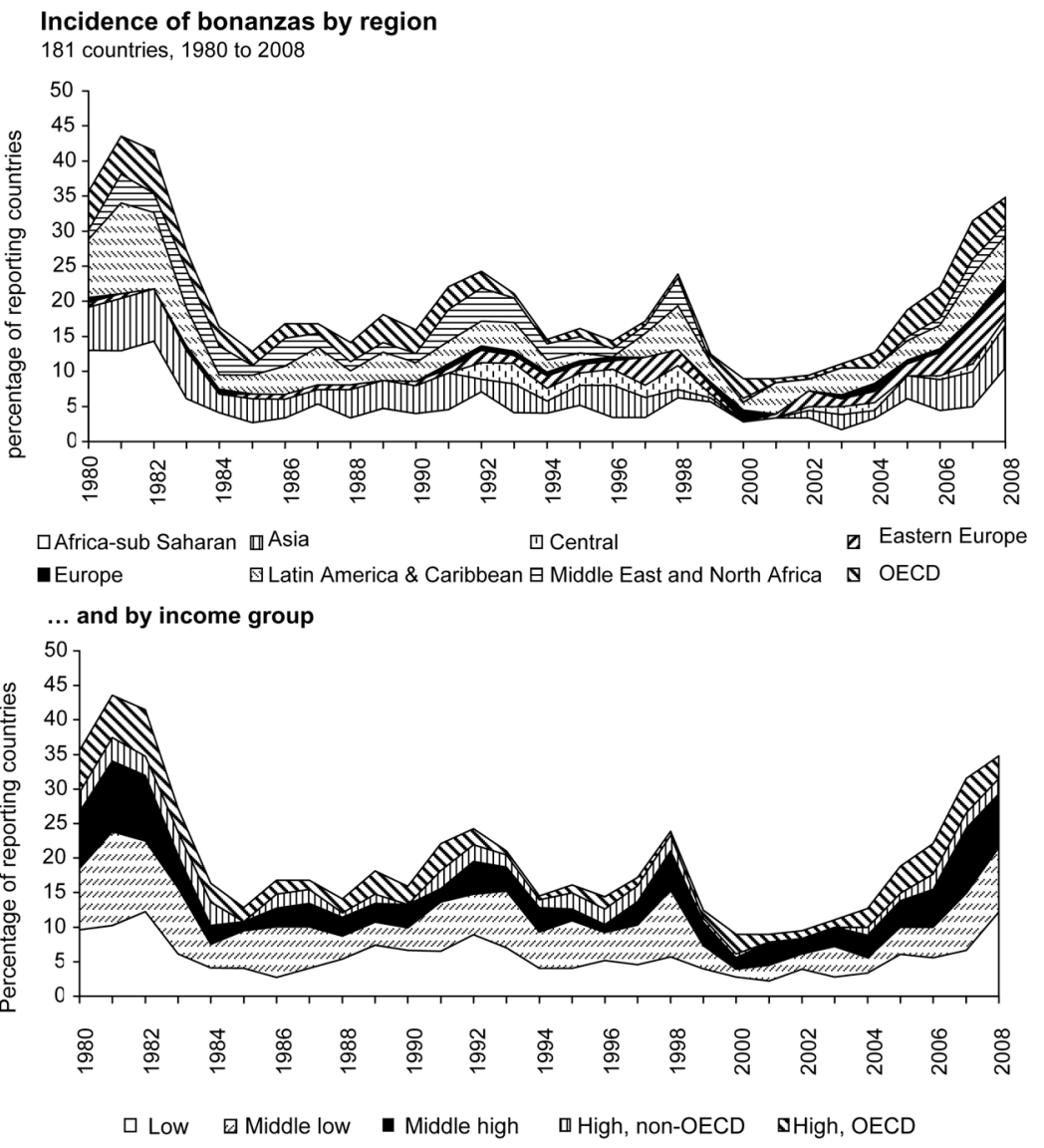

Fig. 2. Incidence of bonanzas by region and income group: 181 countries, 1980-2007. Sources: International Monetary Fund, World Economic Outlook (April 2008), and authors' calculations.

our core sample of 66 countries, which account for about $90 \%$ of world GDP, the bonanza dates for 1960-2007 are listed in table 3.

As the top panel of the figure illustrates, the last major "boom in booms" was the early 1980s. To be more precise, as the core sample reveals for the longer 1960-2007 period, the upswing of this cycle was from 1975 to 1982, or just before the onset of the debt crisis of the 1980s. Prior to 1975, capital flow bonanzas were fewer and further between, consistent with the historical evidence presented in Eichengreen and Adalet (2005). Capital flow bonanzas resurfaced in the early 1990s coinciding with a decline in U.S. interest rates (see Calvo et al. 1993; Chuhan, Claessens, and Mamingi 1998) and the large-scale Brady plan restructuring of emerging 
Table 3

Dates of Capital Flow Bonanzas: Core Sample, 1960-2007

\begin{tabular}{|c|c|}
\hline Country & Years of Bonanzas \\
\hline \multicolumn{2}{|l|}{ High income, OECD: } \\
\hline Australia & 1965, 1986, 1989, 2004-5, 2007 \\
\hline Austria & $1972-74,1976-77,1979-81,1995-97,1999$ \\
\hline Belgium & $1967-68,1975-84$ \\
\hline Canada & $1975-79,1981,1989-93$ \\
\hline Denmark & $1969-70,1974-77,1979,1981-82,1984-87$ \\
\hline Finland & $1975-76,1980,1988-92$ \\
\hline France & $1966-67,1969,1974,1976,1982-83,2005-7$ \\
\hline Germany & $1980,1991,1994-95,1999-2000$ \\
\hline Greece & $1983,1985,2000,2006-7$ \\
\hline Italy & $1974,1980-82,1991-92$ \\
\hline Korea & $1980-83,1991,1996$ \\
\hline New Zealand & $1974-75,1982,1984-85,2005-7$ \\
\hline Norway & $1974-79,1986-89,1998$ \\
\hline Portugal & $1981-82,2000-2001,2005$ \\
\hline Spain & $1965-66,1974,1976,2000,2004-7$ \\
\hline Sweden & $1976-77,1979-82,1990-92$ \\
\hline United Kingdom & $1960-76,1988-90,2005-7$ \\
\hline United States & $2002-7$ \\
\hline \multicolumn{2}{|l|}{ High income, non-OECD: } \\
\hline Hong Kong, SAR & $1980-81,1994-97$ \\
\hline Singapore & $1980-84,1987$ \\
\hline \multicolumn{2}{|l|}{ Middle-high income: } \\
\hline Argentina & $1982,1987,1994,1997-99$ \\
\hline Brazil & $1974-83,1999,2001$ \\
\hline Chile & $1978,1980-82,1984-86$ \\
\hline Costa Rica & $1970-83,1989-90$ \\
\hline Hungary & 1986-87, 1993-94, 1998-99, 2003-4 \\
\hline Malaysia & $1981-83,1991,1994-95$ \\
\hline Mauritius & $1979-82,2006-7$ \\
\hline Mexico & $1974-76,1979-81,1991-94$ \\
\hline Panama & $1967-73,1975-82,1997-98,2007$ \\
\hline Poland & $1980-81,1985-89$ \\
\hline Romania & $1992,2004-7$ \\
\hline Russia & 1992,1997 \\
\hline South Africa & $1981-82,2005-7$ \\
\hline Turkey & $1977,1980,2000,2004-7$ \\
\hline Uruguay & $1980-84,2001$ \\
\hline Venezuela & $1967,1977-78,1982,1987-88,1992-93,1998$ \\
\hline \multicolumn{2}{|l|}{ Middle-low income: } \\
\hline Algeria & $1969,1973,1975-79,1986,1988-89,1994-95,1998$ \\
\hline Angola & $1982,1995,1997-99,2001$ \\
\hline Bolivia & $1978-79,1981,1985-87,1993,1998$ \\
\hline China & $1979,1985-86,1988-89,1993$ \\
\hline Colombia & $1971,1982-83,1995,1997-98$ \\
\hline Dominican Republic & $1966-70,1972-73,1975-82,1987$ \\
\hline Ecuador & $1978,1981-82,1987,1989,1991,1998$ \\
\hline Egypt & $1967-71,1974-76,1979,1981-85,1998$ \\
\hline
\end{tabular}


Table 3

Continued

\begin{tabular}{ll}
\hline Country & \multicolumn{1}{c}{ Years of Bonanzas } \\
\hline El Salvador & $1978,1989,1990,2003,2005,2007$ \\
Guatemala & $1981,1987,1992-93,1994,1999,2001$ \\
Honduras & $1974-75,1978-81,1984,2003-4,2007$ \\
Indonesia & $1967-73,1975,1982-83,1986-87,1991,1995$ \\
Morocco & $1976-77,1981,1983-87$ \\
Nicaragua & $1988,1990-94$ \\
Paraguay & $1980-82,1986-87,1996$ \\
Peru & $1973-77,1981-83,1993,1995,1998$ \\
Philippines & $1975-80,1982-83,1990,1993,1997$ \\
Sri Lanka & $1979-84,1986,1988$ \\
Thailand & $1975-77,1981-83,1990-91,1995-96$ \\
Tunisia & $1981-84,1986,1993$ \\
Low income: & \\
Central African Republic & $1980,1982-84,1992-95$ \\
Côte d'Ivoire & $1980,1988-92$ \\
India & $1984,1987-90$ \\
Kenya & $1980-81,1987,1989,1995$ \\
Myanmar & $1981-82,1990-92,1998$ \\
Nigeria & $1981-83,1986,1993,2002$ \\
Zambia & $1981-82,1998,2000-2001$ \\
Zimbabwe & $1981-82,1992,2004-5$ \\
\hline
\end{tabular}

Note: The dates shown are those picked up by the algorithm described in the preceding section. Consecutive years (e.g., Greece 2000, 2001) are treated as a single episode.

market debt. This resurgence was modest and occurred in a more selective group of countries-a feature well documented by the World Bank (1997). With Uruguay in 2002 marking the last major crisis in emerging markets, bonanzas have reappeared in force. The regional breakdown indicates that the recipients in this latest wave include countries in Latin America, mostly smaller ones benefiting from the commodity-price boom, industrial countries in which real estate prices had been rising rapidly, and the nations of central and eastern Europe and the former Soviet Union, presumably being rewarded for closer integration with the European Union. ${ }^{9}$

Illustrated in the bottom panel of the figure is the well-publicized empirical regularity that middle- and high-income countries receive the lion's share of cross-border capital flows. This is true by a huge margin when flows are measured in U.S. dollar terms and remains so when we calculate the incidence of bonanzas (which scale current account deficits by GDP). Despite the fact that low-income countries account for $28 \%$ (50 countries) of the 181 countries in this sample, fewer than 18 countries have recorded a capital bonanza in any given year during the past 
30 years or so. The incidence of capital flow bonanzas is far less cyclical for the low-income group. On the basis of these observations, we base our more in-depth analysis of capital flow bonanzas and their link to financial crises in the next two sections on a group of 66 countries, of which 58 are middle or high income. ${ }^{10}$

The two panels in figure 3 provide complementary information on the duration of bonanzas. The upper panel plots the maximum duration of bonanzas (in years) by countries (rather than episodes). So, for example, six of the 181 countries never experienced a capital inflow bonanza since they are net capital exporters; this group includes Brunei, Luxembourg, Namibia, the Netherlands, Switzerland, and the United Arab Emirates. For most countries, bonanzas lasted somewhere between 2 and 4 years, which is perhaps why so many governments (and investors) fall into the all-too-common trap of treating bonanzas as permanent rather than transitory shocks-an issue we take up later when examining the typical fiscal response to the abundance of foreign capital.

We turn now to an analysis of individual episodes. Consistent with their cyclical nature, three-quarters of the episodes identified during 1980-2007 last 2 years or less. Some caution is in order in that there are a large number of instances in which bonanza episodes are separated by a single year, which de facto makes the bonanza episode much longer and adds to the ex ante confusion as to what is permanent and what is transitory. The present U.S. bonanza, which began in 2002 and was into its sixth consecutive year by 2007, is by no means common, but neither is it unique. Australia and the United Kingdom, among others, experienced similar long-lived bonanzas in the earlier (1960-79) period, as table 3 makes plain.

\section{B. The Capital Flow Cycle and World Commodity Prices}

Capital inflow surges have often been linked to reductions in international interest rates, economic growth in advanced economies, and global commodity price booms. ${ }^{11}$ In the remainder of this section, we briefly revisit the well-trodden path of the external roots of capital flow bonanzas. Our primary aim in this paper-beyond establishing systematically the dates and incidence of capital inflow bonanzas-is to focus on the macroeconomic consequences or developments surrounding capital flows (a topic that takes up the next two sections of the paper). As such, we provide only a mere sketch of the links between the bonanza cycle and selected developments in global macroeconomic conditions, so as to build on earlier analyses using the most recent data. 
Maximum duration of bonanzas

181 countries, 1980 to 2008

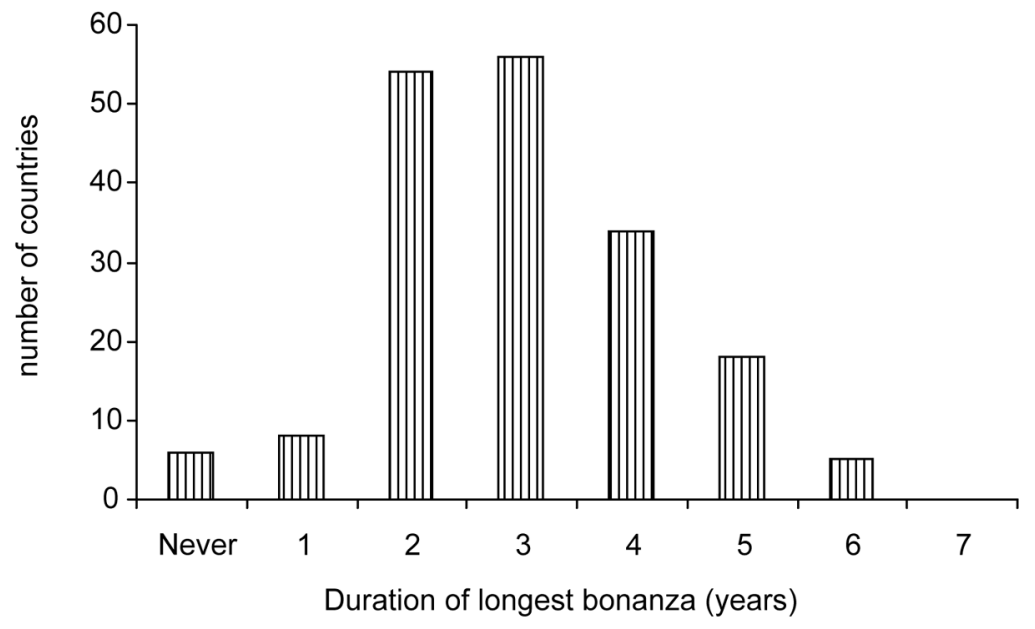

Distribution of the length of bonanzas

181 countries, 1980 to 2008

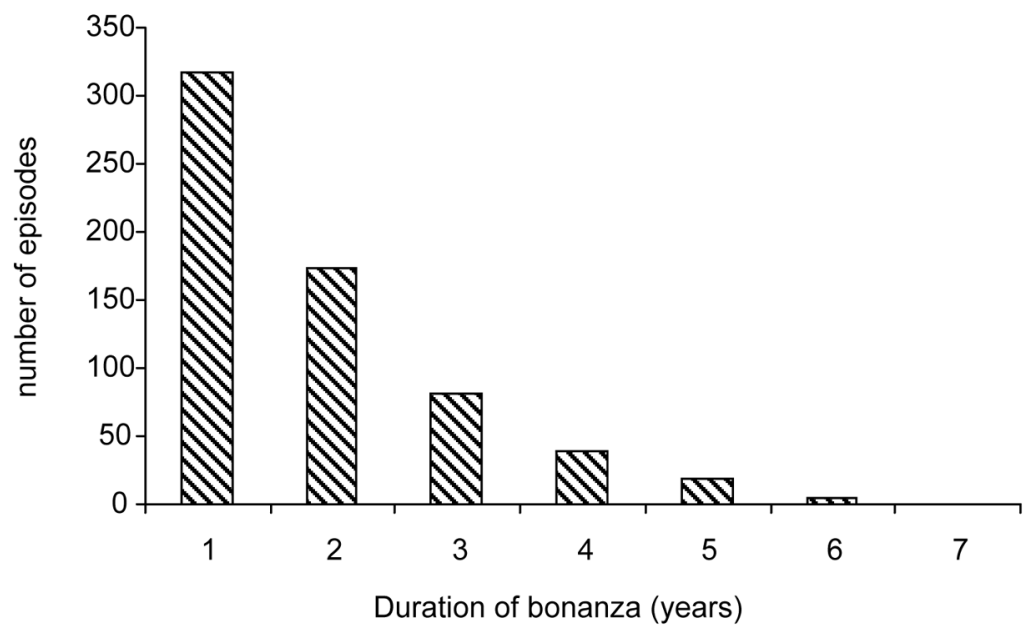

Fig. 3. Characteristics of bonanzas, 181 countries, 1980-2008. Sources: Authors' calculations and data cited in table 3. 
To this end, we perform two simple exercises. First, we plot our time series on the incidence of bonanzas for the 181-country sample over 1980-2007 against (i) real per capita GDP growth in the advanced economies, as reported in the IMF's World Economic Outlook (upper panel of fig. 4); and (ii) the IMF's index of real commodity prices, excluding oil (bottom panel of fig. 4). ${ }^{12}$ The evidence presented in the top panel of figure 4 is in line with evidence of Calvo et al. (1993), who posit that when growth slows in the advanced economies, global capital searches for higher yields and profit opportunities abroad in emerging marketsa phenomenon that is well under way at the current conjuncture, as discussed in Frankel (2007) in the context of the carry trade and its previous incarnations. The capital flow bonanza-commodity price boom link has

The occurrence of capital flow bonanzas and real growth in the Advanced Economies

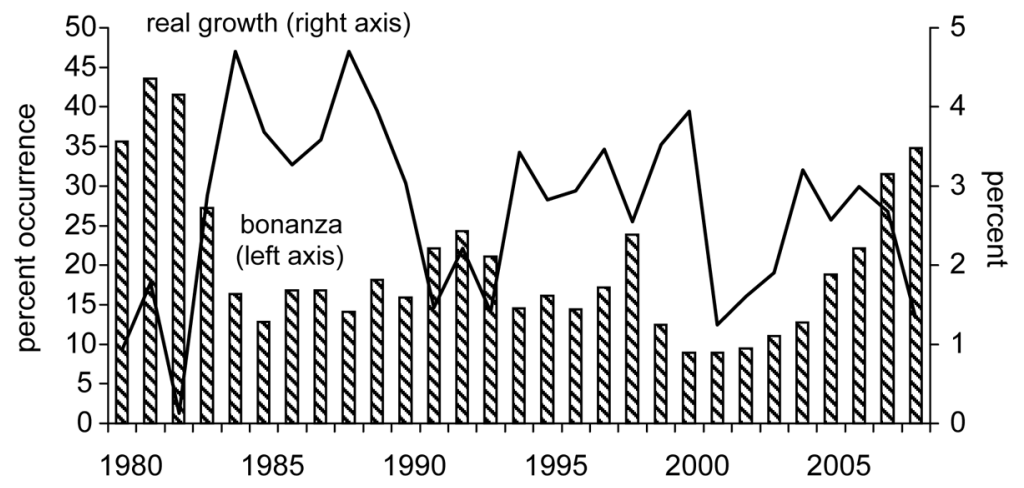

... and non-oil commodity prices

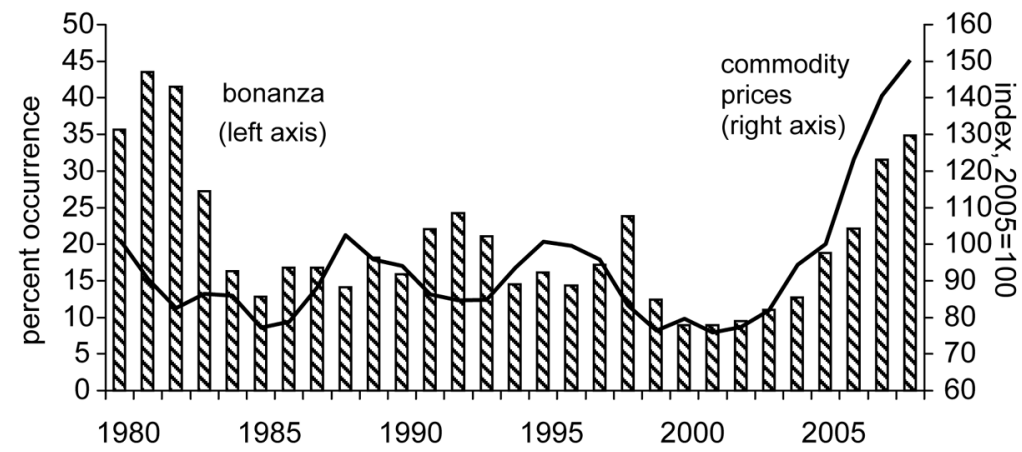

Fig. 4. Capital flow bonanzas, advanced economies' growth performance, and world commodity prices: 181 countries, 1980-2007. Sources: Authors' calculations and data cited in app. table A3. 
an old history, and some classic episodes of well-managed (in terms of the macroeconomic policy response) and badly botched varieties make for interesting reading in Cuddington (1989) and sources cited therein. While the earlier 1980s do not fit the pattern as neatly, it is important to note that a spectacular boom in commodity prices prevailed in the late 1970s when the surge in the incidence of bonanzas began in earnest, as shown in the next section. Beyond the direct positive implications of higher commodity prices for export revenues for much of the emerging world, as Frankel (2006, 2008a, 2008b) demonstrates, an underlying impetus to world commodity prices is low or negative world interest rates, much along the lines of the late 1970s and the last few years. Hence, the effects of lower international interest rates work through not only the portfolio channels stressed in Calvo et al. (1993) but also the commodity price channel à la Frankel (2006). A third and important link between world real interest rates and capital flows to emerging markets comes from the channel stressed by Dooley, Fernandez-Arias, and Kletzer (1996), who emphasize the benign impacts of low real rates on default probabilities.

Our second empirical exercise is an attempt to explain the share of bonanzas in terms of the growth of real GDP in the advanced economies, real commodity prices, and the U.S. real short-term interest rate. We employ the core data set to capture the significant swing in real commodity prices as well as the long stretch of negative real interest rates in the United States in the 1970s. Our dependent variable is contained in a limited range, from zero to $100 \%$ as befits a share of a total. Accordingly, we specify that our independent variables explain the dependent variable by way of a logistic function. That is, the explanatory variables, along with a vector of ones to capture a constant term, are aligned in the vector $x_{t}$ with corresponding coefficients in the vector $\beta$ to obey the functional form $100 \cdot \exp \left(x_{t} \beta\right) /\left[1+\exp \left(x_{t} \beta\right)\right]$.

The coefficients reported in the first column of table 4 were estimated with a maximum likelihood procedure using annual data from 1967 to 2006. As this is a probability forecasting model, the goodness-of-fit measure we rely on chiefly is the quadratic probability score (QPS), for the reasons explained in Diebold and Rudebusch (1989).

As anticipated in the figures, the coefficient on commodity prices is positive and that on growth is negative; both are statistically significant at the $1 \%$ confidence level. The coefficient on the contemporaneous real interest rate, however, does not match the intuition provided in Calvo et al. (1993). Their explanation relies on the cumulative encouragement 
Table 4

Logistic Models Explaining the Probability of a Capital Flow Bonanza Estimated with Annual Data from 1967 to 2006

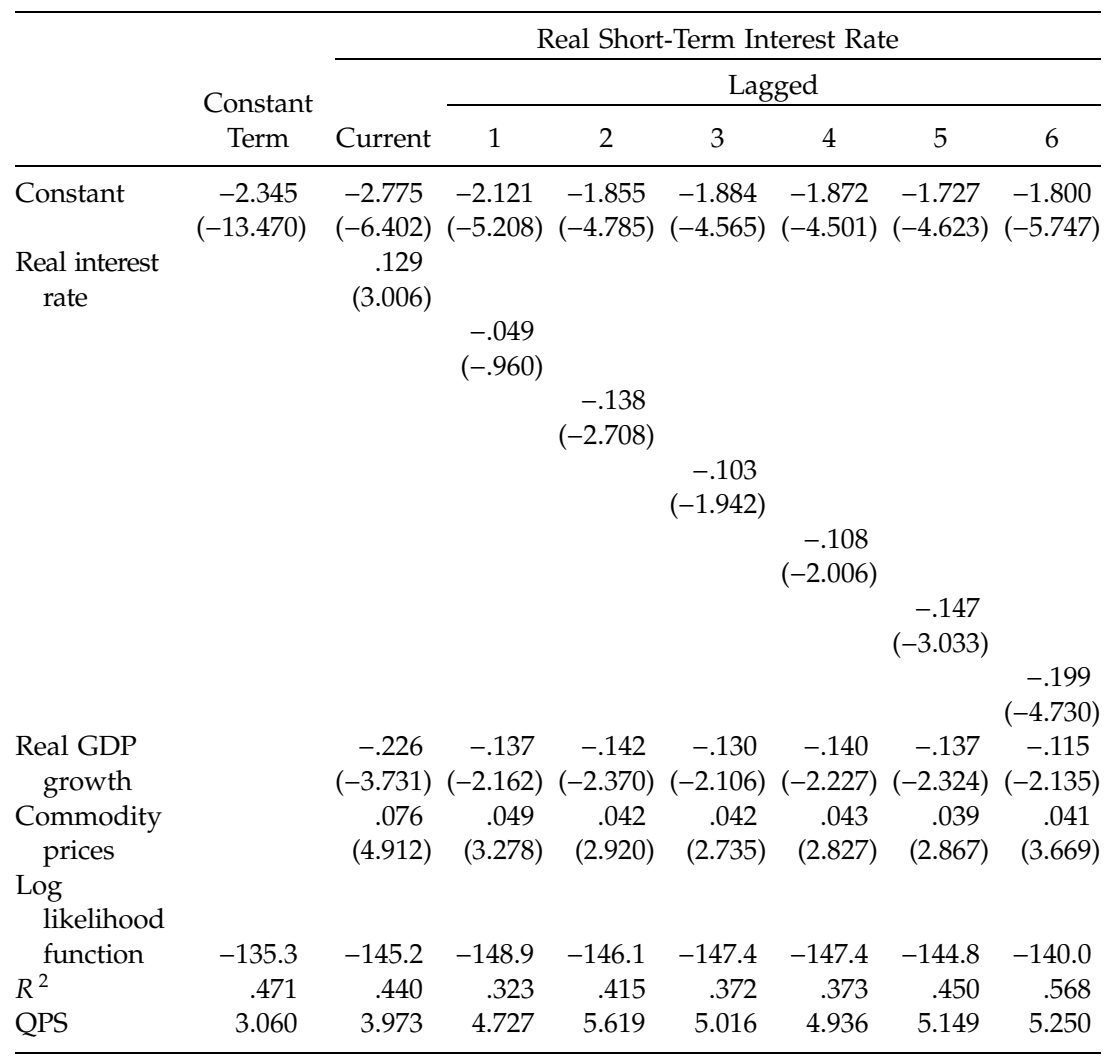

Sources: Authors' calculations and data cited in app. table A3.

Note: $t$-statistics are in parentheses.

to capital flows to the periphery afforded by low interest rates at the core. To match this, the next six columns of the table report estimates using successive individual lags of the real rate, from 1 to 6 years. In the event, the size of the negative effect of real rates on the share and the significance of that effect, as well as the explanatory power of the model, tends to increase as the lag lengthens.

\section{Do Capital Flow Bonanzas Make Countries More Crisis Prone?}

Are capital flow bonanzas a blessing, a curse, or neutral in making financial crises more likely or more severe? The literature is filled with famous 
case studies of capital flow bonanzas that ended in spectacular crises. The papers range from the infamous episodes in the Southern Cone in the late 1970s to early 1980s (see, e.g., Diaz-Alejandro's [1985] classic) to Calvo and Talvi (2005), which places great store in the capital flow sudden stop following the Russian 1998 crisis in explaining Argentina's subsequent crash. Rather than focusing on specific episodes that are either as famous or more obscure, we systematically examine the potential links between the likelihood of a capital inflow bonanza and financial crises. Our analysis is conducted on a country-by-country basis as well as at the "global" level consistent with the aim of providing an encompassing approach. Our comprehensive database on the dates of bonanza and crises episodes allows us to uncover novel results on the systematic connection between the incidence of bonanzas and debt, currency, inflation, and banking crises. Hence, our analysis sheds light on the first part of the question of whether financial crises are more likely; it remains for future research to investigate issues glimpsed here pertaining to a possible link between the order of magnitude of the bonanza and the severity of the crises. The latter part of the section is devoted to more general macroeconomic volatility (as opposed to crises).

\section{A. Bonanzas and Financial Crises: Preamble and Evidence}

Section II delineated the criteria used to define a capital flow bonanza and catalogued, country by country, all the identified bonanza episodes. To examine the potential links with financial crises of various stripes, we proceed symmetrically. Our crisis analysis is taken directly from Reinhart and Rogoff (2008b). These crises definitions are reproduced in table 5, and a full listing of dates for sovereign external defaults (or restructurings), currency crashes, inflation crises, and banking crises are presented in table 6 for 64 of the 66 core countries for which we have dates on capital flow bonanzas. ${ }^{13}$ In line with our dating of bonanzas, table 6 provides beginning and ending dates to define each crisis episode. Hence, an entry of a single year denotes that the crises lasted only that long.

From the crises dates shown in table 6 and the bonanza dates listed in table 3 , we constructed a family of country-specific probabilities. For each of the countries, this implies four unconditional crisis probabilities: that of default (or restructuring) on external sovereign debt, a currency crash, an inflation crisis, and a banking crisis. We also construct the probability of each type of crisis within a window of 3 years before and after the bonanza year or years; we refer to this as the conditional probability of a crisis. If capital flow bonanzas make countries more crisis prone, the 
Table 5

Defining Crises by Events: A Summary

\begin{tabular}{|c|c|c|}
\hline Type of Crisis & Definition and/or Criteria & Comments \\
\hline Banking crisis & $\begin{array}{l}\text { We mark a banking crisis by } \\
\text { two types of events: (1) bank } \\
\text { runs that lead to the closure, } \\
\text { merging, or takeover by the } \\
\text { public sector of one or more } \\
\text { financial institutions; and } \\
\text { (2) if there are no runs, the } \\
\text { closure, merging, takeover, } \\
\text { or large-scale government } \\
\text { assistance of an important } \\
\text { financial institution (or } \\
\text { group of institutions) that } \\
\text { marks the start of a string of } \\
\text { similar outcomes for other } \\
\text { financial institutions. }\end{array}$ & $\begin{array}{l}\text { This approach to dating the } \\
\text { beginning of the banking } \\
\text { crises is not without } \\
\text { drawbacks. It could date the } \\
\text { crises too late, because the } \\
\text { financial problems usually } \\
\text { begin well before a bank is } \\
\text { finally closed or merged; it } \\
\text { could also date the crises too } \\
\text { early, because the worst of a } \\
\text { crisis may come later. Unlike } \\
\text { external debt crises (see } \\
\text { below), which have } \\
\text { well-defined closure dates, } \\
\text { it is often difficult or } \\
\text { impossible to accurately } \\
\text { pinpoint the year in which } \\
\text { the crisis ended. }\end{array}$ \\
\hline External debt crises & $\begin{array}{l}\text { A sovereign default is defined } \\
\text { as the failure to meet a } \\
\text { principal or interest } \\
\text { payment on the due date (or } \\
\text { within the specified grace } \\
\text { period). The episodes also } \\
\text { include instances in which } \\
\text { rescheduled debt is } \\
\text { ultimately extinguished in } \\
\text { terms less favorable than the } \\
\text { original obligation. }\end{array}$ & $\begin{array}{l}\text { While the time of default is } \\
\text { accurately classified as a } \\
\text { crisis year, there are a large } \\
\text { number of cases in which } \\
\text { the final resolution with the } \\
\text { creditors (if it ever did take } \\
\text { place) seems interminable. } \\
\text { For this reason we also work } \\
\text { with a crisis dummy that } \\
\text { picks up only the first year. }\end{array}$ \\
\hline Inflation crisis & $\begin{array}{l}\text { An annual inflation rate of } \\
20 \% \text { or higher. We also } \\
\text { examine separately the } \\
\text { incidence of more extreme } \\
\text { cases in which inflation } \\
\text { exceeds } 40 \% \text { per year. }\end{array}$ & $\begin{array}{l}\text { All consecutive years in which } \\
\text { the threshold is met or } \\
\text { exceeded are counted as } \\
\text { a part of the same inflation } \\
\text { crisis. }\end{array}$ \\
\hline Currency crash & $\begin{array}{l}\text { An annual depreciation vs. the } \\
\text { U.S. dollar (or the relevant } \\
\text { anchor currency-historically } \\
\text { the U.K. pound, the French } \\
\text { franc, or the German deutsche } \\
\text { mark and presently the euro) } \\
\text { of } 15 \% \text { or more. This is } \\
\text { similar to the Frankel and } \\
\text { Rose (1996) approach to } \\
\text { dating crashes. }\end{array}$ & $\begin{array}{l}\text { In parallel treatment to the } \\
\text { inflation crisis dating, } \\
\text { all consecutive years in } \\
\text { which the threshold is met } \\
\text { or exceeded are counted as a } \\
\text { part of the same inflation } \\
\text { crisis. }\end{array}$ \\
\hline
\end{tabular}

Source: Reinhart and Rogoff (2008b). 
Table 6

Dates of Economic Crises: Core Sample, 1960-2007

\begin{tabular}{|c|c|c|c|c|}
\hline \multirow[b]{2}{*}{ Country } & \multicolumn{4}{|c|}{ Within 3 Years of the Bonanza } \\
\hline & $\begin{array}{l}\text { External } \\
\text { Default }\end{array}$ & $\begin{array}{l}\text { Currency } \\
\text { Crash }\end{array}$ & $\begin{array}{l}\text { Inflation } \\
\text { Crisis }\end{array}$ & $\begin{array}{l}\text { Banking } \\
\text { Crisis }\end{array}$ \\
\hline \multicolumn{5}{|l|}{$\begin{array}{l}\text { High income, } \\
\text { OECD: }\end{array}$} \\
\hline Australia & & $\begin{array}{l}1976,1982 \\
1985,1997 \\
2000\end{array}$ & 1966,1975 & 1989-92 \\
\hline Austria & & 2005 & & \\
\hline Belgium & & 1982,2005 & & \\
\hline Canada & & & & $1983-85$ \\
\hline Denmark & & & & 1987-92 \\
\hline Finland & & 1967,1992 & & 1991-94 \\
\hline France & & 1976, 2005 & & 1994-95 \\
\hline Germany & & $\begin{array}{r}1984,1997 \\
1999,2005\end{array}$ & & $1977-79$ \\
\hline Greece & & $\begin{array}{l}\text { 1976, 1980, } \\
\text { 1983, } \\
\text { 1985-86, } \\
1990,2005\end{array}$ & & 1991-95 \\
\hline Italy & & $\begin{array}{l}1976,1992 \\
2005\end{array}$ & 1974,1980 & 1990-95 \\
\hline Korea & $1998^{\mathrm{a}}$ & $\begin{array}{l}1966,1970 \\
1975,1979-80 \\
1997\end{array}$ & $\begin{array}{l}\text { 1974, } \\
1980-81\end{array}$ & $\begin{array}{c}1982,1985-88 \\
1997-2002\end{array}$ \\
\hline New Zealand & & $\begin{array}{c}1976,1980-82 \\
1987,1989\end{array}$ & & 1987-90 \\
\hline Norway & & 1982,1986 & & 1987-93 \\
\hline Portugal & & $\begin{array}{l}\text { 1976-77, } \\
1981-84,2005\end{array}$ & $\begin{array}{l}1974, \\
1982-84\end{array}$ & \\
\hline Spain & & $\begin{array}{l}1967,1977 \\
1982,1993 \\
2005\end{array}$ & 1977 & 1977-85 \\
\hline Sweden & & $\begin{array}{r}1977,1982 \\
1992,2005\end{array}$ & & 1991-94 \\
\hline United Kingdom & & $\begin{array}{r}1967,1975-76 \\
1981-83,1993\end{array}$ & 1975 & $\begin{array}{l}\text { 1974-76, 1984, } \\
1991,1995,2007\end{array}$ \\
\hline United States & & $\begin{array}{l}1969,1971 \\
1975\end{array}$ & & 1984-91, 2007 \\
\hline \multicolumn{5}{|l|}{$\begin{array}{l}\text { High income, } \\
\text { non-OECD: }\end{array}$} \\
\hline $\begin{array}{l}\text { Hong Kong, } \\
\text { SAR }\end{array}$ & & 1983 & & 1982-86, 1998 \\
\hline $\begin{array}{r}\text { Singapore } \\
\text { Middle-high } \\
\text { income: }\end{array}$ & & 1997 & 1973 & 1982 \\
\hline Argentina & $\begin{array}{l}1956-65 \\
1982-93 \\
2001-5\end{array}$ & $\begin{array}{l}\text { 1965-71, } \\
1974-91 \\
2002\end{array}$ & $\begin{array}{l}\text { 1965-67, } \\
1971-92 \\
2002\end{array}$ & $\begin{array}{l}1980-82 \\
1995-96 \\
2001-3\end{array}$ \\
\hline
\end{tabular}


Table 6

Continued

\begin{tabular}{|c|c|c|c|c|}
\hline \multirow[b]{2}{*}{ Country } & \multicolumn{4}{|c|}{ Within 3 Years of the Bonanza } \\
\hline & $\begin{array}{l}\text { External } \\
\text { Default }\end{array}$ & $\begin{array}{l}\text { Currency } \\
\text { Crash }\end{array}$ & $\begin{array}{l}\text { Inflation } \\
\text { Crisis }\end{array}$ & $\begin{array}{c}\text { Banking } \\
\text { Crisis }\end{array}$ \\
\hline Brazil & 1983-94 & $\begin{array}{l}\text { 1965-71, } \\
\text { 1974-95, } \\
\text { 1999, 2001-2 }\end{array}$ & $\begin{array}{r}1965-71 \\
1974-95\end{array}$ & $\begin{array}{c}1985,1990 \\
1994-97\end{array}$ \\
\hline Chile & $\begin{array}{r}1965,1972 \\
1974-75 \\
1983-90\end{array}$ & $\begin{array}{l}1962-79 \\
1982-85 \\
1987,1989\end{array}$ & $\begin{array}{l}\text { 1962-80, } \\
\text { 1983, 1985, } \\
1990-91\end{array}$ & $1982-84$ \\
\hline Costa Rica & $1981-90$ & $\begin{array}{l}\text { 1974, 1981, } \\
\text { 1987, 1991, } \\
1995\end{array}$ & $\begin{array}{l}1974, \\
\text { 1981-83, 1988, } \\
1991-92,1995\end{array}$ & $1987,1994-96$ \\
\hline Hungary & $1941-67$ & $1993,1995-97$ & $\begin{array}{r}1990-93 \\
1995-96\end{array}$ & 1991-95 \\
\hline Malaysia & & 1998 & & $\begin{array}{l}\text { 1985-88, } \\
1997-2001\end{array}$ \\
\hline Mauritius & & $\begin{array}{c}1979,1981 \\
1983-84\end{array}$ & 1979-81 & \\
\hline Mexico & $\begin{array}{c}1982-90 \\
1995^{\mathrm{a}}\end{array}$ & $\begin{array}{l}1976,1982-87 \\
1989,1994-95 \\
1999\end{array}$ & $\begin{array}{c}1976-77 \\
1980-92 \\
1995-96\end{array}$ & $\begin{array}{l}\text { 1981-82, } \\
1994-2000\end{array}$ \\
\hline Panama & 1983-96 & & & 1988-89 \\
\hline Poland & 1981-94 & 1987-95 & 1996-97, 1999 & 1991-95 \\
\hline Romania & $\begin{array}{c}1981-83 \\
1986\end{array}$ & $\begin{array}{r}1973,1983 \\
1990-2001\end{array}$ & 1990-2002 & 1990-99 \\
\hline Russia & 1991-2000 & $\begin{array}{l}\text { 1987-96, } \\
1998-99\end{array}$ & $\begin{array}{l}\text { 1993-97, } \\
\text { 1998-2001 }\end{array}$ & 1995,1998 \\
\hline South Africa & $\begin{array}{l}\text { 1985-87, } \\
1989,1993\end{array}$ & $\begin{array}{l}\text { 1967, 1982, } \\
\text { 1984-85, 1988, } \\
\text { 1996, 1998 } \\
2000-2001\end{array}$ & & 1977 \\
\hline Turkey & $1978-79,1982$ & $\begin{array}{l}\text { 1971, } \\
\quad 1977-2001\end{array}$ & 1977-2003 & $1982-84,1994$ \\
\hline Uruguay & $\begin{array}{l}1983,1987 \\
1990,2003\end{array}$ & $\begin{array}{c}\text { 1967-86, } \\
1970-72, \\
1974-97 \\
2001-2\end{array}$ & 1964-96 & 1981-84, 2002 \\
\hline Venezuela & $1983-88,1990$ & $\begin{array}{c}\text { 1984, 1986, } \\
\text { 1989-96, } \\
2002-4\end{array}$ & $\begin{array}{l}\text { 1980, 1983-88, } \\
\text { 1990, 1995-97, } \\
2004-5\end{array}$ & $\begin{array}{l}\text { 1978-86, } \\
1993-94\end{array}$ \\
\hline \multicolumn{5}{|c|}{ Middle-low income: } \\
\hline Algeria & 1991-96 & $\begin{array}{l}\text { 1988-91, } \\
1994-95\end{array}$ & 1991-95 & 1990-92 \\
\hline Angola & 1985-2003 & $\begin{array}{l}1966-73 \\
1991-2003\end{array}$ & $\begin{array}{l}\text { 1974-80, } \\
1991-2005\end{array}$ & 1992-97 \\
\hline Bolivia & $\begin{array}{l}\text { 1980-84, } \\
1986-97\end{array}$ & $\begin{array}{l}\text { 1972, 1979, } \\
\text { 1982-85, } \\
1987,1989\end{array}$ & $\begin{array}{c}1973-75 \\
1979-86 \\
1991\end{array}$ & $\begin{array}{l}\text { 1986-87, } \\
1994-97\end{array}$ \\
\hline
\end{tabular}


Table 6

Continued

\begin{tabular}{|c|c|c|c|c|}
\hline \multirow[b]{2}{*}{ Country } & \multicolumn{4}{|c|}{ Within 3 Years of the Bonanza } \\
\hline & $\begin{array}{c}\text { External } \\
\text { Default }\end{array}$ & $\begin{array}{l}\text { Currency } \\
\text { Crash }\end{array}$ & $\begin{array}{l}\text { Inflation } \\
\text { Crisis }\end{array}$ & $\begin{array}{l}\text { Banking } \\
\text { Crisis }\end{array}$ \\
\hline China & & $\begin{array}{r}1984,1986 \\
1989,1994\end{array}$ & 1994 & 1992-99 \\
\hline Colombia & & $\begin{array}{l}\text { 1979-82, } \\
1985,1987-96\end{array}$ & $\begin{array}{l}1980-91, \\
\quad 1995,1997-2000\end{array}$ & 1982-87, 1998 \\
\hline $\begin{array}{r}\text { Dominican } \\
\text { Republic }\end{array}$ & $\begin{array}{l}1982-94 \\
2005\end{array}$ & $\begin{array}{l}1985,1987-88 \\
1990,2003-4\end{array}$ & $\begin{array}{l}\text { 1980, 1984-85, } \\
1988-91,2003-5\end{array}$ & \\
\hline Ecuador & $\begin{array}{l}\text { 1982-95, } \\
1999-2000\end{array}$ & $\begin{array}{c}1971,1982-92 \\
1995-2000\end{array}$ & $1974,1983-2001$ & $\begin{array}{c}\text { 1981, 1984, } \\
\text { 1988, 1991, } \\
1996-2002\end{array}$ \\
\hline Egypt & 1983 & $\begin{array}{c}\text { 1979, 1989-91, } \\
2001,2003\end{array}$ & $\begin{array}{l}\text { 1980, 1986-87, } \\
\text { 1989-90, } 1992\end{array}$ & $\begin{array}{c}\text { 1981-83 } \\
1990-95\end{array}$ \\
\hline El Salvador & & 1973,1988 & $\begin{array}{l}\text { 1985-87, 1990, } \\
1993\end{array}$ & 1989 \\
\hline Guatemala & 1986,1989 & $1986,1989-90$ & $1986,1990-91$ & \\
\hline Honduras & 1981-2007 & $\begin{array}{l}\text { 1990, 1993-94, } \\
1996\end{array}$ & $\begin{array}{l}\text { 1990-91, } \\
1994-97\end{array}$ & \\
\hline Indonesia & $\begin{array}{l}\text { 1966-70, } \\
\text { 1998-2000, } \\
2002\end{array}$ & $\begin{array}{l}1962-68,1978 \\
1983,1986 \\
1997-98,2000\end{array}$ & $\begin{array}{c}1960-68,1979 \\
1998-99\end{array}$ & $\begin{array}{r}1992,1994, \\
1996-2002\end{array}$ \\
\hline Morocco & $1983,1986-90$ & 1985 & & $1983-84$ \\
\hline Nicaragua & 1983-2007 & $1979,1985-93$ & $1973,1979-92$ & 1987-96 \\
\hline Paraguay & $\begin{array}{c}1968-69 \\
1986-92 \\
2003-4\end{array}$ & $\begin{array}{c}\text { 1984-86, 1989, } \\
\text { 1992-93, } \\
\text { 1998-99, } \\
2001-2\end{array}$ & $\begin{array}{l}\text { 1974, 1979-80, } \\
1984-91,1994\end{array}$ & 1995-2000 \\
\hline Peru & $\begin{array}{c}1969,1976 \\
1978,1980 \\
1983-97\end{array}$ & 1976-93, 1998 & 1975-94 & $1983-90$ \\
\hline Philippines & $1983-92$ & $\begin{array}{l}\text { 1971, 1983-84, } \\
\text { 1990, 1997, } \\
2000\end{array}$ & $\begin{array}{r}1973-74 \\
1984-85\end{array}$ & $\begin{array}{l}\text { 1981-87, } \\
\text { 1997-2001 }\end{array}$ \\
\hline Sri Lanka & $1979,1981-93$ & & & 1989-93 \\
\hline Thailand & & $\begin{array}{l}\text { 1984, 1997, } \\
2000\end{array}$ & 1974 & $\begin{array}{l}\text { 1980-87, } \\
\text { 1996-2001 }\end{array}$ \\
\hline Tunisia & 1979-82 & $\begin{array}{l}1974,1978 \\
1986\end{array}$ & & \\
\hline \multicolumn{5}{|l|}{ Low income: } \\
\hline $\begin{array}{l}\text { Central African } \\
\text { Republic }\end{array}$ & $\begin{array}{l}\text { 1981, } \\
\quad 1983-2007\end{array}$ & 1994 & 1994 & $\begin{array}{r}1976-82 \\
1988-99\end{array}$ \\
\hline Côte d'Ivoire & $\begin{array}{l}\text { 1983-98, } \\
2000-2007\end{array}$ & 1994 & $\begin{array}{l}\text { 1977, 1979, } \\
1994\end{array}$ & 1988-91 \\
\hline India & $1969,1972-76$ & $\begin{array}{l}1967,1984 \\
1988,1991 \\
1993\end{array}$ & $1973-74$ & 1993-98 \\
\hline Kenya & 1994-98, 2000 & & $1984,1992-94$ & $\begin{array}{l}\text { 1985-89, } \\
\text { 1992-95 } \\
\text { (continued }\end{array}$ \\
\hline
\end{tabular}


Table 6

Continued

\begin{tabular}{|c|c|c|c|c|}
\hline \multirow[b]{2}{*}{ Country } & \multicolumn{4}{|c|}{ Within 3 Years of the Bonanza } \\
\hline & $\begin{array}{l}\text { External } \\
\text { Default }\end{array}$ & $\begin{array}{l}\text { Currency } \\
\text { Crash }\end{array}$ & $\begin{array}{l}\text { Inflation } \\
\text { Crisis }\end{array}$ & $\begin{array}{l}\text { Banking } \\
\text { Crisis }\end{array}$ \\
\hline Myanmar & $2002-7$ & 1975 & $\begin{array}{l}1966,1973-76 \\
1988-98 \\
2001-3,2006\end{array}$ & 1996-2003 \\
\hline Nigeria & $\begin{array}{r}1987-94 \\
2004-5\end{array}$ & $\begin{array}{l}1972,1981, \\
1985-92,1999\end{array}$ & $\begin{array}{l}\text { 1975, 1977, } \\
1981,1983-84 \\
1988-89 \\
1992-96\end{array}$ & $1992-96$ \\
\hline Zambia & 1983-94 & $\begin{array}{l}1983-86 \\
1988-96 \\
1998,2000\end{array}$ & 1984-2003 & 1995 \\
\hline Zimbabwe & 2000-2007 & $\begin{array}{l}1982-84 \\
1988-2006\end{array}$ & $\begin{array}{l}\text { 1983-84, } \\
1991-2006\end{array}$ & 1995-2006 \\
\hline
\end{tabular}

Source: Reinhart and Rogoff (2008b) and sources cited therein.

Note: These include all crises (by type) around the bonanzas. Crisis definitions are presented in table 5 .

${ }^{\mathrm{a} A}$ near default episode.

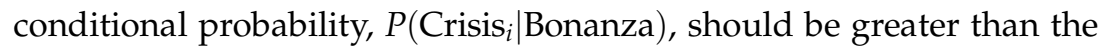
unconditional probability of a crisis, $P\left(\mathrm{Crisis}_{i}\right)$, where the subscript $i$ refers to the ith "type" of crisis (default, currency, etc.).

Table 7 aggregates these country-specific conditional and unconditional probabilities by three groups (all countries, high-income, and middle- and low-income). The test statistic for the equality between two proportions,

$$
Z=\frac{p_{1}-p_{2}}{\left\{P(1-P)\left[\left(1 / n_{1}\right)+\left(1 / n_{2}\right)\right]\right\}^{1 / 2}},
$$

where $P=\left(p_{1} n_{1}+p_{2} n_{2}\right) /\left(n_{1}+n_{2}\right)$, is calculated for each pair of probabilities, where $n_{1}=n_{2}$ is the number of observations in each group. The instances in table 7 in which the difference in proportions is significantly different at the $1 \%$ confidence level are marked with an asterisk.

The main results are summarized as follows. For the full sample, the probability of any of the four varieties of crises conditional on a capital flow bonanza is significantly higher than the unconditional probability. Put differently, the incidence of a financial crisis is higher around a capital inflow bonanza. However, separating the high-income countries from the rest qualifies the general result. As for the high-income group, there are no systematic differences between the conditional and unconditional probabilities. 
Table 7

Are Bonanza Episodes More Crisis Prone? Core Sample, 1960-2007

\begin{tabular}{|c|c|c|c|c|}
\hline Probability of Crisis (in Percent) & $\begin{array}{l}\text { External } \\
\text { Default }\end{array}$ & $\begin{array}{l}\text { Currency } \\
\text { Crash }\end{array}$ & $\begin{array}{l}\text { Inflation } \\
\text { Crisis }\end{array}$ & $\begin{array}{c}\text { Banking } \\
\text { Crisis }\end{array}$ \\
\hline & \multicolumn{4}{|c|}{ High Income } \\
\hline Conditional on a bonanza (3-year window) & .2 & 9.5 & 2.6 & 11.9 \\
\hline Unconditional & .0 & 8.2 & 2.1 & 11.2 \\
\hline \multirow[t]{2}{*}{ Difference } & .2 & 1.3 & .5 & .7 \\
\hline & \multicolumn{4}{|c|}{ Middle and Low Income } \\
\hline Conditional on a bonanza (3-year window) & 29.6 & 31.5 & 31.7 & 20.7 \\
\hline Unconditional & 21.0 & 22.7 & 23.5 & 14.3 \\
\hline \multirow[t]{2}{*}{ Difference } & $8.6^{*}$ & $8.8^{*}$ & $8.2^{*}$ & $6.4^{*}$ \\
\hline & \multicolumn{4}{|c|}{ All Countries } \\
\hline Conditional on a bonanza (3-year window) & 22.2 & 25.8 & 24.2 & 18.4 \\
\hline Unconditional & 15.7 & 19.1 & 18.0 & 13.2 \\
\hline Difference & $6.5^{*}$ & $6.7^{*}$ & $6.2^{*}$ & $5.2^{*}$ \\
\hline $\begin{array}{l}\text { Percentage of countries for which conditional } \\
\text { probability is greater than unconditional }\end{array}$ & 42.2 & 65.6 & 59.4 & 60.9 \\
\hline
\end{tabular}

Sources: Based on tables 2 and 4 and authors' calculations.

Note: The 3-year window encompasses 3 years before the bonanza years listed in table 2, the year (or years if these are consecutive) of the bonanza, and the 3 years following the episode.

*Significant at the $1 \%$ confidence level.

These results are not entirely surprising since the high-income countries do not default on their sovereign debts during the sample in question. ${ }^{14}$ Given that the threshold that defines an inflation crisis is $20 \%$ per year, it is also hardly a surprise that this cutoff is seldom surpassed by wealthy countries-whether experiencing a capital flow bonanza or not. It is less obvious, a priori, that there is no discernible increase in the likelihood of a banking or currency crisis for the advanced economies. The bottom row of table 7 provides the share of countries for which $P\left(\right.$ Crisis $_{i} \mid$ Bonanza $) \geq P\left(\right.$ Crisis $\left._{i}\right)$ as an additional indication of how commonplace it is across countries to see bonanzas associated with a more crisis-prone environment. For sovereign defaults, less than half the countries record an increase in default probabilities around capital flow bonanzas. (Here, it is important to recall that about one-third of the countries in the core sample are high income.) For currency, banking, and inflation crises, the majority of countries register a higher propensity to enter into a crisis around bonanza periods.

Beyond the aggregate results presented in table 7, figures 5-8 for debt, currency, inflation, and banking crises, respectively, present a 


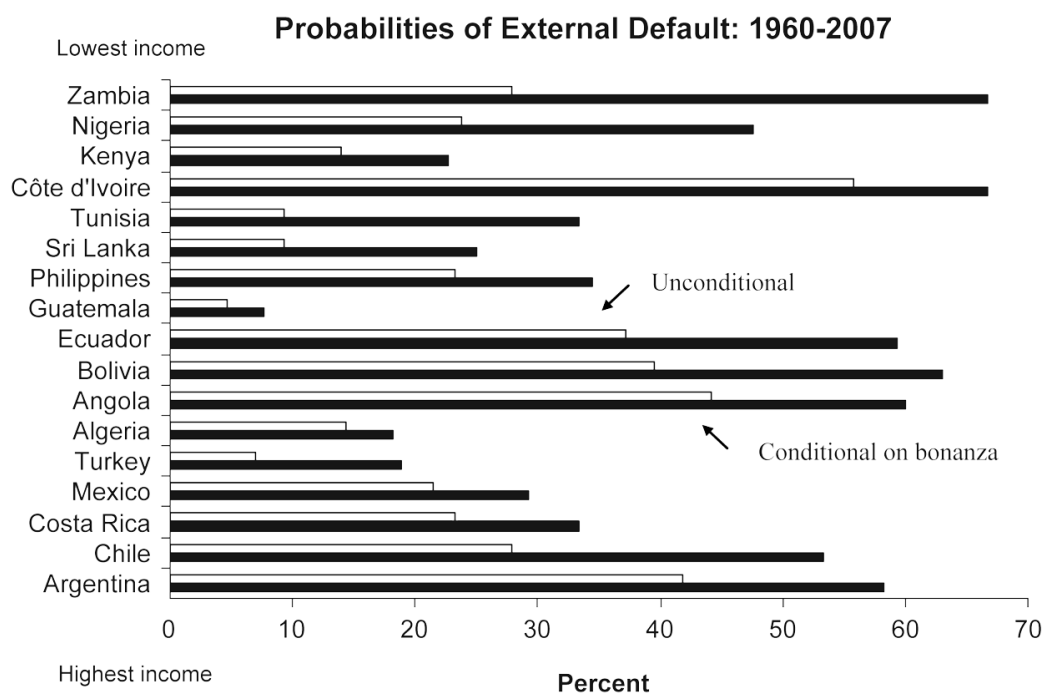

Fig. 5. Are bonanza episodes more crisis prone? Sovereign external default, 66 countries, 1960-2007. Sources: Authors' calculations, Reinhart and Rogoff (2008b), and sources cited therein.

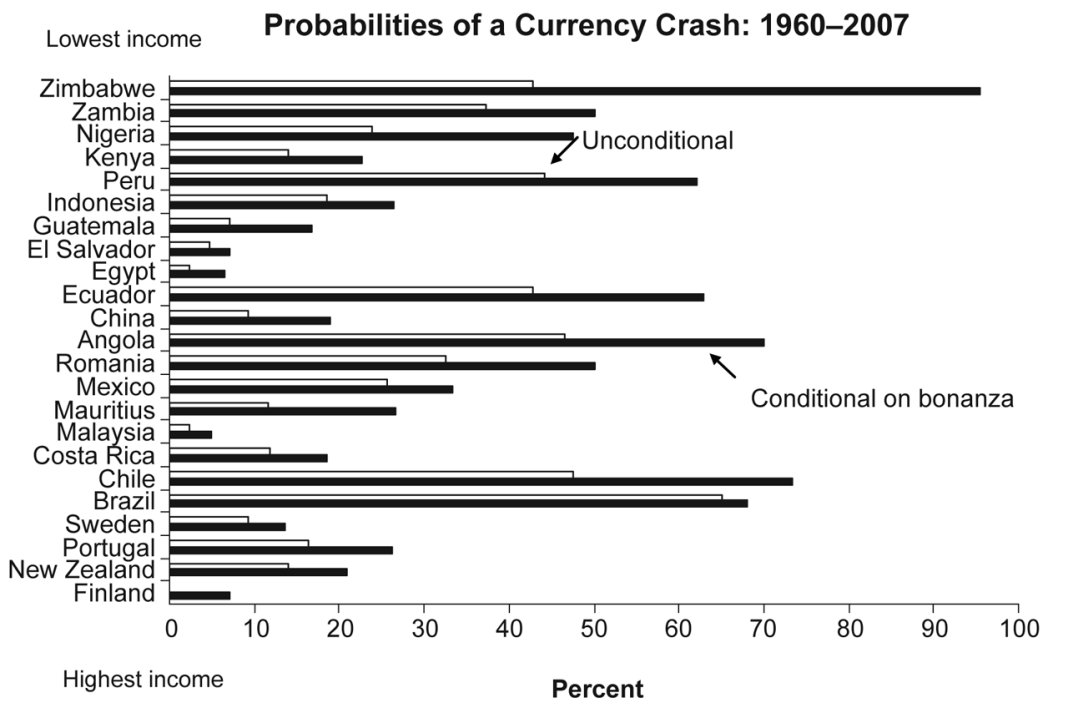

Fig. 6. Are bonanza episodes more crisis prone? Currency crashes, 66 countries, 1960-2007. Sources: Authors' calculations, Reinhart and Rogoff (2008b), and sources cited therein. 
Lowest income Probabilities of an Inflation Crisis: 1960-2007

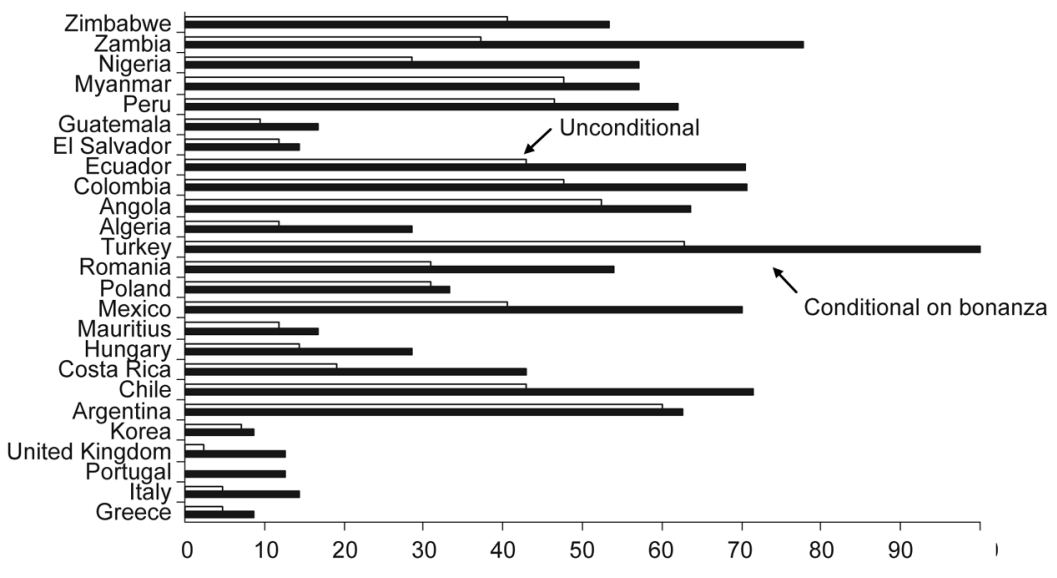

Highest income

Percent

Fig. 7. Are bonanza episodes more crisis prone? Inflation crises, 66 countries, 1960-2007. Sources: Authors' calculations, Reinhart and Rogoff (2008b), and sources cited therein.

Lowest income Probabilities of a Banking Crisis: 1960-2007

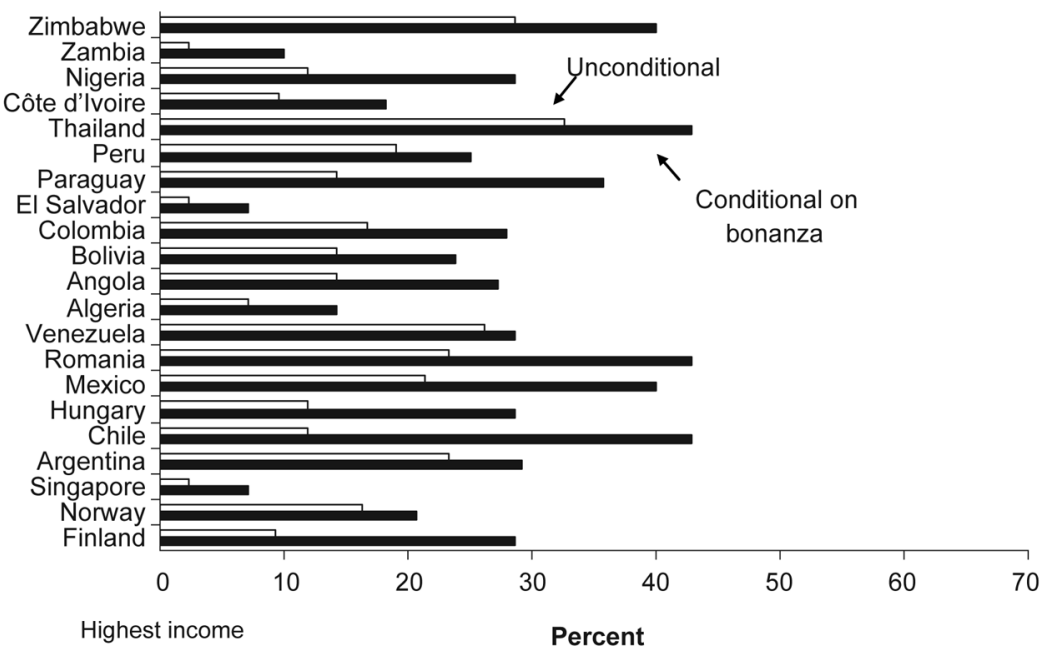

Fig. 8. Are bonanza episodes more crisis prone? Banking crises, 66 countries, 1960-2007. Sources: Authors' calculations, Reinhart and Rogoff (2008b), and sources cited therein. 
comparison of conditional and unconditional probabilities for individual countries, where the differences in crisis probabilities were greatest. (Hence, the country list varies across figures.) As noted earlier, no high-income country turns up in figure 5 on debt crises. The same cannot be said of figures 6-8. While the advanced economies register much lower (conditional and unconditional) crisis probabilities than their lower-income counterparts, the likelihood of a crisis is higher around bonanza episodes in several instances. Notably, Finland and Norway record a higher probability of a banking crisis during the vicinity of a capital flow bonanza, whereas Greece, Italy, and the United Kingdom show a greater predisposition to an inflation crisis when bonanzas are present.

\section{B. Bonanzas as a Predictor of Sovereign Defaults}

Beyond the country-by-country comparisons described in the preceding section, we wanted to refine further the relationship between bonanzas and sovereign defaults. As discussed in Reinhart and Rogoff (2008b) in the context of the evidence from 1800-2007, there is an intimate connection between the global capital flows (as measured annually in terms of U.S. dollars) and default (exactly as measured here, by the incidence of sovereign default). A variant of this relationship is presented in figure 9,

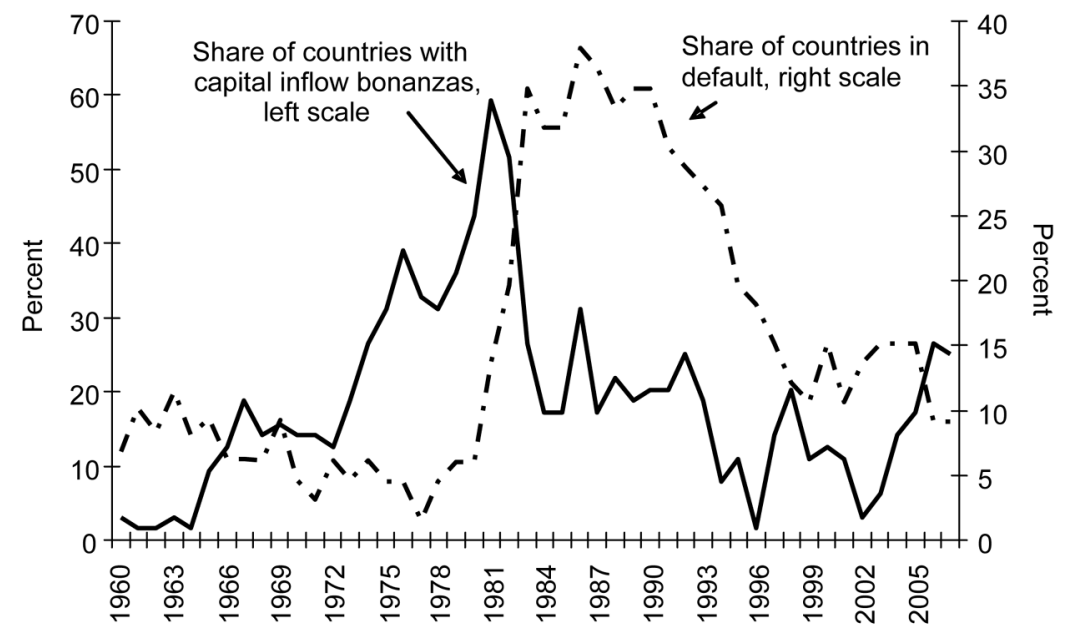

Fig. 9. Capital flow bonanzas as predictors of sovereign default, 66 countries, 1960-2007. Sources: Authors' calculations, Reinhart and Rogoff (2008b), and sources cited therein. 
which plots the annual incidence of capital flow bonanzas during 19602007 for the core sample and the comparable incidence on sovereign default. The overall incidence is higher and more variable than that shown in figure 1 for the 181 countries, since the core sample predominantly represents countries that have access to international capital markets and, in particular, private flows. A cursory inspection of this figure is suggestive that the incidence of bonanzas possibly "leads" the incidence of default. This temporal pattern would seem plausible in light of the fact that capital inflows to developing countries have historically been predominantly debt-creating flows. ${ }^{15}$ As the bonanza continues, leverage (usually public and private) increases. ${ }^{16}$

To investigate this possibility formally, we ran a series of logistic regressions in which the dependent variable is the aggregate or global probability of sovereign default against the aggregate or global probability of a capital flow bonanza, either contemporaneous or lagged anywhere between 1 year and 6 years. As in the prior section, this functional form respects the limited range of the dependent variable. These results are summarized in table 8 along the column headings for lags up to 6 years. As the results indicate, the fit of regression improves steadily as the lag length is extended up to 6 years. The single bonanza regressor is statistically significant at the $1 \%$ level for the regressions, where the $t$-statistics appear in parentheses. The preferred specification (six lags) yields an $R^{2}$ of about 0.50 . Similarly, the QPS statistic falls. As in the previous discussion on determinants, the global factors behind bonanzas, this exercise is meant to be illustrative rather than a self-contained model of sovereign default. It is worth mentioning that this external default time series registers a contemporaneous correlation with world real interest rates of 0.59 , underscoring that there are multiple factors beyond bonanzas that determine the likelihood of a sovereign debt crisis. These results would not be unfamiliar to the reader of Mendoza and Terrones (2008), who conclude that not all credit booms end in financial crises, but most emerging markets crises were associated with credit booms.

\section{Bonanzas and Macroeconomic Volatility}

Crises, like bonanzas, are discrete, traumatic, and (in the more stable countries) relatively rare. Yet another possibility in which capital flow bonanzas would be less than a blessing might be if these bouts of capital inflows led to an overall increase in macroeconomic volatility, even if it did not increase the odds of a financial crisis outright. To shed some light on this issue, we performed some simple exercises involving 
Table 8

Logistic Models Explaining the Probability of Default: Estimated with Annual Data from 1967 to 2006

\begin{tabular}{|c|c|c|c|c|c|c|c|c|}
\hline & \multirow[b]{3}{*}{$\begin{array}{c}\text { Constant } \\
\text { Term }\end{array}$} & \multicolumn{7}{|c|}{ Share of Countries with Capital Flow Bonanzas } \\
\hline & & \multirow[b]{2}{*}{ Current } & \multicolumn{6}{|c|}{ Lagged } \\
\hline & & & 1 & 2 & 3 & 4 & 5 & 6 \\
\hline Constant & $\begin{array}{c}-1.637 \\
(-14.2)\end{array}$ & $\begin{array}{l}-1.526 \\
(-6.5)\end{array}$ & $\begin{array}{l}-1.778 \\
(-7.7)\end{array}$ & $\begin{array}{l}-1.989 \\
(-9.0)\end{array}$ & $\begin{array}{c}-2.093 \\
(-10.0)\end{array}$ & $\begin{array}{c}-2.211 \\
(-11.1)\end{array}$ & $\begin{array}{c}-2.323 \\
(-12.6)\end{array}$ & $\begin{array}{c}-2.345 \\
(-13.5)\end{array}$ \\
\hline Bonanza & & $\begin{array}{l}-.005 \\
(-.5)\end{array}$ & $\begin{array}{l}.007 \\
(.7)\end{array}$ & $\begin{array}{l}.016 \\
(2.1)\end{array}$ & $\begin{array}{c}.021 \\
(3.0)\end{array}$ & $\begin{array}{c}.027 \\
(4.1)\end{array}$ & $\begin{array}{c}.031 \\
(5.4)\end{array}$ & $\begin{array}{l}.033 \\
(6.0)\end{array}$ \\
\hline $\begin{array}{l}\text { Log } \\
\text { likelihood } \\
\text { function }\end{array}$ & -148.1 & & -147.8 & & -144.3 & -141.4 & -137.4 & -135.3 \\
\hline $\begin{array}{l}R^{2} \\
\text { QPS }\end{array}$ & $\begin{array}{r}.000 \\
1.921\end{array}$ & $\begin{array}{r}.008 \\
1.906\end{array}$ & $\begin{array}{r}.014 \\
1.895\end{array}$ & $\begin{array}{r}.091 \\
1.747\end{array}$ & $\begin{array}{r}.173 \\
1.589\end{array}$ & $\begin{array}{r}.284 \\
1.375\end{array}$ & $\begin{array}{r}.413 \\
1.129\end{array}$ & $\begin{array}{r}.471 \\
1.018\end{array}$ \\
\hline
\end{tabular}

Sources: Authors' calculations and data cited in app. table A3.

Note: $t$-statistics are in parentheses.

the volatilities of real GDP growth, consumer price inflation, and the current account/GDP ratio. Needless to say, this only skims the surface of the potential links between bonanzas and macroeconomic volatility.

We measure volatility as the 66th percentile of the absolute annual change in each macroeconomic variable. Table 9 reports for the full sample the simple pairwise correlations between the incidence of capital

\section{Table 9}

Incidence of Bonanzas and Volatility: 181 Countries, 1980-2007

\begin{tabular}{lc}
\hline Volatility & Correlation \\
\hline Real GDP growth & .43 \\
Inflation & .25 \\
Current account to GDP & .39 \\
\hline
\end{tabular}

Sources: International Monetary Fund World Economic Outlook and authors' calculations. Note: We measure volatility as the 66th percentile of the absolute annual change in each macroeconomic variable. 
inflow bonanzas from 1981 to 2007 and the volatility (as described above) of real GDP growth, inflation, and the current account to GDP. For all three variables the correlation is positive (ranging from a low of 0.25 for inflation to a high of 0.43 for real GDP growth) and statistically significant. Of course, this exercise does not speak of causality or how representative this "global" bonanza-volatility link plays out for individual countries.

\section{Anatomy of Bonanza Episodes}

The macroeconomic developments associated with surges in capital inflows are a mixture of anecdotal evidence from case studies and more systematic analyses that (to our knowledge) have no standardized definition of "a capital inflow episode" or bonanza. ${ }^{17}$ The collective evidence from this literature suggests that capital inflows are most often associated with both a deterioration in the current account and an accumulation in international reserves, ostensibly from the central bank's persistent efforts to avoid or mitigate the tendency toward a nominal and real exchange rate appreciation that usually goes hand-in-hand with the capital inflow. ${ }^{18}$ As Calvo et al. (1993) document in several papers, the pressures for the exchange rate to appreciate stem both from an increased demand for the local assets (which may or may not lead to an asset price boom or bubble) and from an increase in aggregate demand for both traded and nontraded goods. As long as the supply of the nontraded good is not perfectly elastic, the relative price of nontradables increases (i.e., a real exchange rate appreciation).

In an attempt to analyze the cyclical behavior of fiscal policy in advanced and emerging market economies, Kaminsky, Reinhart, and Végh (2004) present evidence for emerging markets of the "when it rains, it pours" phenomenon; that is to say, that the cyclical components of GDP, net capital flows, and real fiscal spending all reinforce each other. Periods of cyclically high capital inflows are associated with an expansion in real government spending: fiscal policy is procyclical in relation to both output and capital inflows.

Some of these macroeconomic trends, notably the worsening current account, appreciating real exchange rates, and rising asset prices, regularly present themselves on the eve of currency and banking crises (Kaminsky and Reinhart 1999) and sudden stops (Edwards 2004, 2007). In the remainder of this section, we extend such comparisons. 


\section{A. Growth, Inflation, and the Current Account}

Capital flow bonanzas-as with sudden stops, current account reversals, and financial crises-each have their own idiosyncrasies. However, these episodes also tend to share common threads that cut across time and national boundaries, which we exploit by opening a wide window of comparison.

Our strategy is to examine the behavior of key macroeconomic and financial indicators in the run-up and aftermath of the identified bonanza episodes, starting with the "big picture." Figure 10 presents four panels showing medians across episodes during 1980-2007 for key macroeconomic

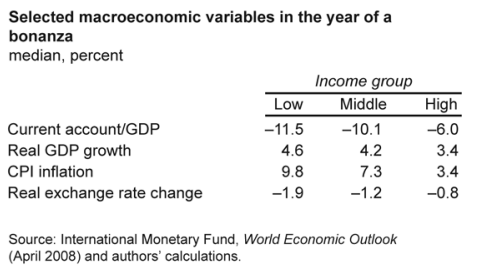

Real GDP growth

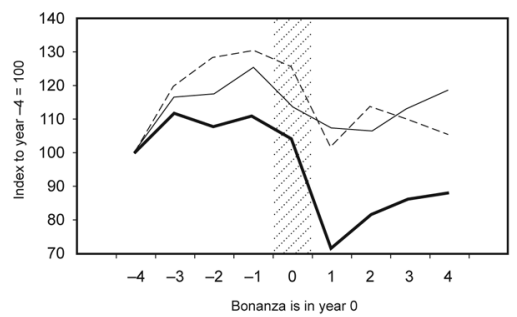

Change in the real-exchange rate

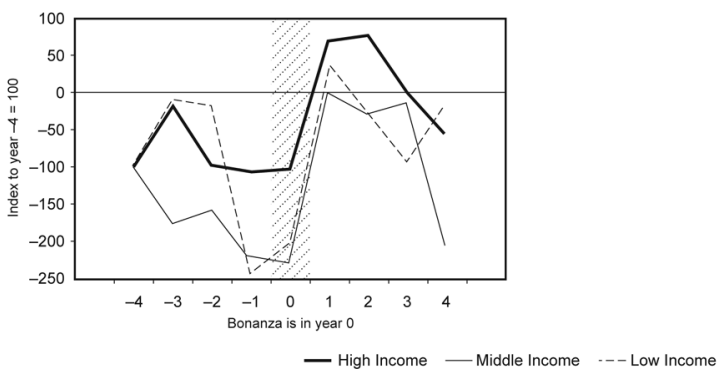

Current account to GDP

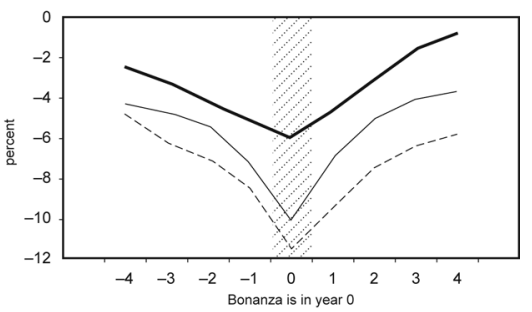

CPI inflation

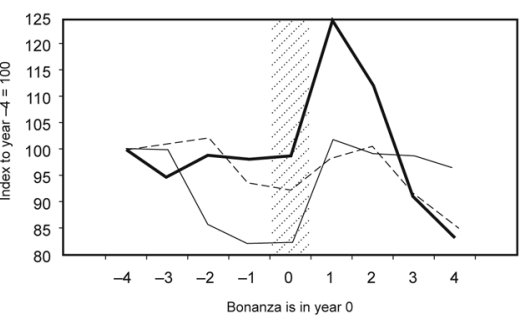

Fig. 10. Growth, inflation, the current account, and real exchange rate around bonanzas, 181 countries, 1980-2007. Sources: International Monetary Fund, World Economic Outlook (April 2008), and authors' calculations. 
indicators: real GDP growth, inflation, the current account balance/GDP ratio, and the real exchange rate. We plot each series from 4 years $(-4)$ before the bonanza (year 0) to 4 years (4) after. Because of the enormous diversity in our 181-country sample, the medians are plotted separately for high-, middle-, and low-income countries (denoted by solid, dashed, and dotted lines, respectively). In line with the findings of several papers on capital account reversals and sudden stops, the average path of the current account balance to GDP (top-right panel) is distinctly V-shaped, with the current account deteriorating into the bonanza year and improving steadily thereafter. Note that this is not an artifact of our selection criteria. We do not select for big changes, only big levels. Current account deficits are, on average, largest for the low-income countries and smallest for the advanced economies, consistent with the evidence reported earlier on cutoff values. The path of the real exchange rate (bottom-left panel) shows that there is a cumulative appreciation (a decline denotes an appreciation) up to the bonanza year and a sharp depreciation afterward. The analysis of Goldfajn and Valdes (1999) presents compelling evidence that in the overwhelming majority of cases, the cumulative real appreciation unwinds through a swift nominal depreciation (perhaps through a full-fledged currency crisis) rather than through a downward adjustment in prices.

GDP growth rises into the bonanza but then slows, settling back to a roughly prebonanza growth rate for middle- and low-income countries and a markedly lower growth rate for high-income economies. As to inflation, the trajectory is so diverse across the three income groups that it is impossible to draw any conclusion as to a fixed behavioral pattern. This suggests that the efforts of central banks in anchoring expectations are more important than the stage of the capital-flow cycle.

This association holds across individual countries as well. Figure 11 provides reinforcing cross-episode evidence via scatter plots that compare the real GDP growth and inflation performance for the year before and after the bonanza. Observations above the 45-degree ray indicate that growth (inflation) is higher 1 year after the bonanza than the year before the bonanza episode; the converse is true for observations below the diagonal. Taken together, these scatter plots confirm that for the most part (63\% of the episodes) growth is lower after the capital inflow boom, whereas no clear pattern emerges for inflation.

The narrative illustrated in figure 12 for the core 66 countries for the longer sample spanning 1960-2007 intimately mirrors the broader post1980 experience; the current account registers a V-shaped pattern, inflation is markedly different for the wealthy and not-so-wealthy countries, 


\section{Real GDP growth}
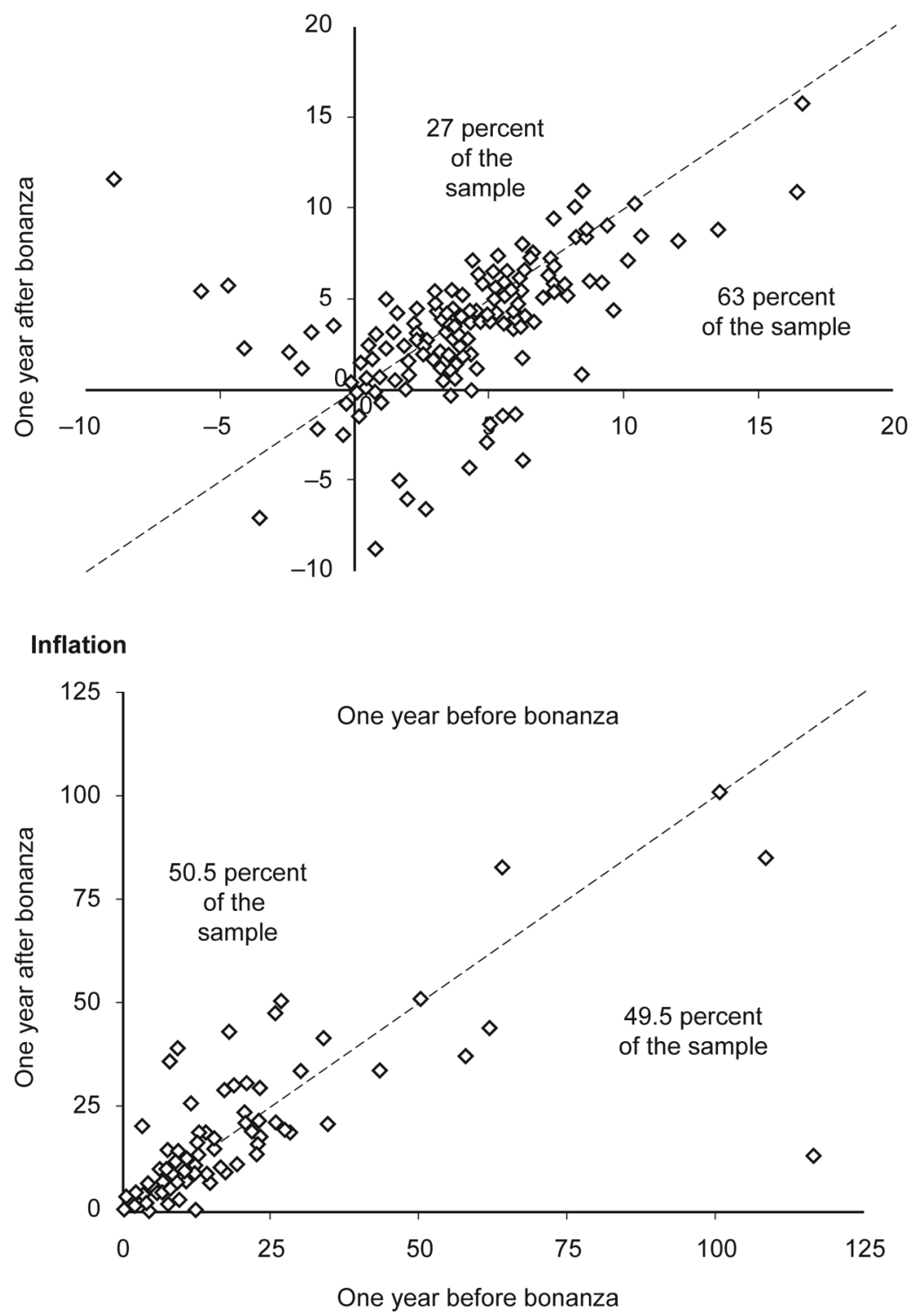

Fig. 11. Before and after: growth and inflation around bonanzas, 181 countries, 1980-2007. Sources: International Monetary Fund, World Economic Outlook (April 2008), and authors' calculations. 


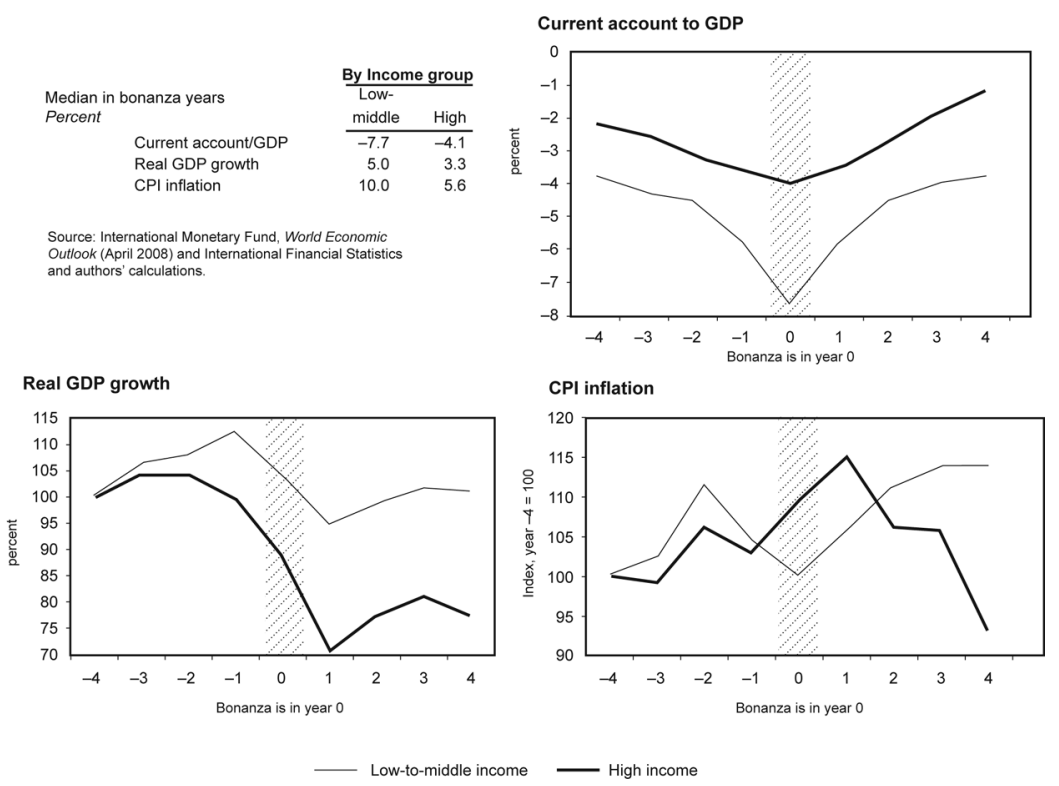

Fig. 12. Growth, inflation, and the current account around bonanzas, 66 countries, 1960-2007. Sources: International Monetary Fund, World Economic Outlook (April 2008), International Financial Statistics, and authors' calculations.

and real growth picks up in the run-up to the bonanza but does worse in the aftermath-particularly for high-income countries. Whatever growth benefits accrue during the bonanza phase are but short lived.

\section{B. External Sector: Reserves, Exchange Rates, and Trade}

There is a blossoming recent literature trying to explain why many emerging market countries have been amassing international reserves at an unprecedented clip. Some studies have stressed a "precautionary" motive in which countries build their war chests in good times to provide liquidity if need be in bad times (see, e.g., Bastourre, Carrera, and Ibarlucia 2008; Carroll and Jeanne 2008). What the upper panel of figure 13 makes plain is that the practice of accumulating reserves, especially in developing countries during capital inflow years (which characterizes the current juncture for many emerging markets), is far from new, since the episodes depicted in this figure span 1960 to the present. Reluctance to allow for a sustained nominal or real exchange rate appreciation is a constant that has withstood the test of time in emerging markets. Tendencies to lean against the wind are seldom more pronounced than when there 


\section{International reserves}

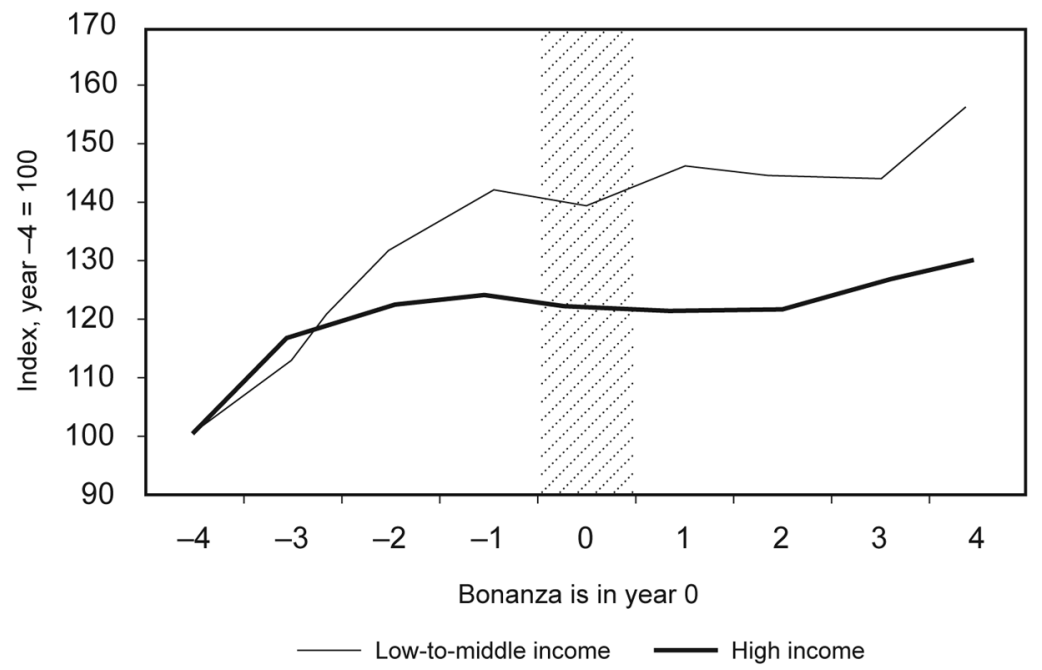

\section{Holdings in 2007}

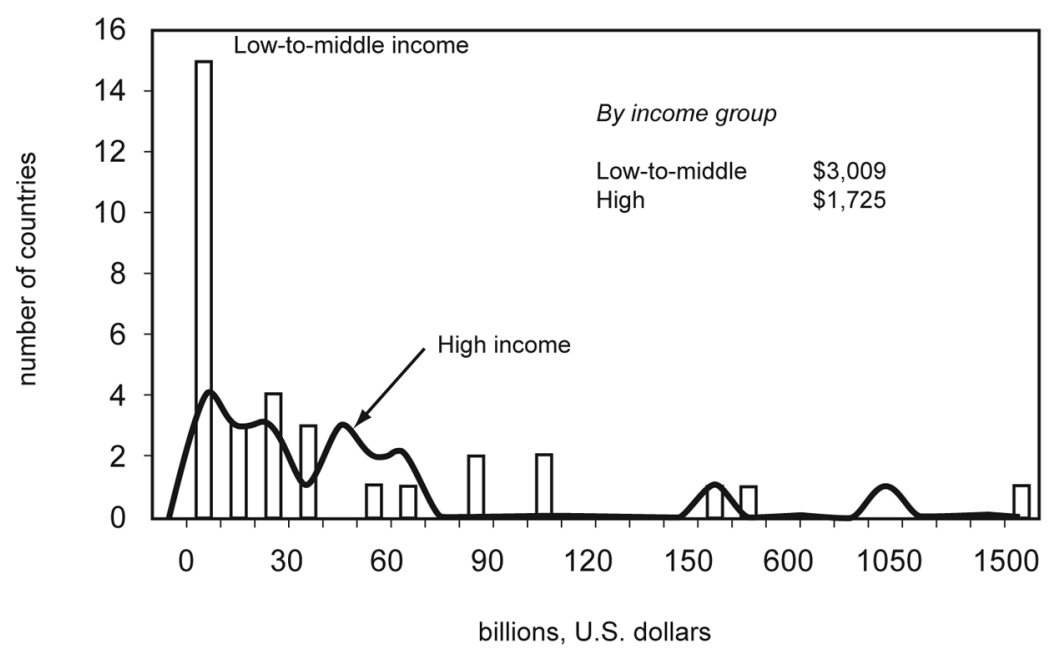

Fig. 13. International reserves around bonanzas, 66 countries, 1960-2007: Sources: International Monetary Fund, World Economic Outlook, and authors' calculations.

is a capital inflow bonanza under way. The $40 \%$ plus increase in reserves in the run-up to the bonanza is no trivial change for the middle- and low-income countries, which as of 2007 held about twice as much in reserves as their high-income counterparts (bottom panel). 
There is little surprising in figure 14, which displays the same graphs for the external indicators (trade balance, exports, imports, and real exchange rate) for the 66-country sample. The trade balance follows the same path of the current account, since imports expand more rapidly than exports at the outset of the bonanza. The real exchange rate initially appreciates and subsequently depreciates in the years immediately following the capital flow bonanza. The only incremental evidence revealed by figure 14 is that the real depreciation shown in the bottom-right panel is noticeably smoother than that shown in figure 9 for the 181-country average after 1980; possibly this difference may reflect that crises are more severe (Kaminsky and Reinhart 1999) and reversals more acute (Eichengreen and Adalet 2005) in the more recent period or that the addition of lower-income countries in the larger sample adds to volatility.

\section{Fiscal Policy: Amplifier or Stabilizer}

Managing surges in capital inflows poses nontrivial policy challenges, particularly if the inflows are persistent and/or if the orders of magnitude
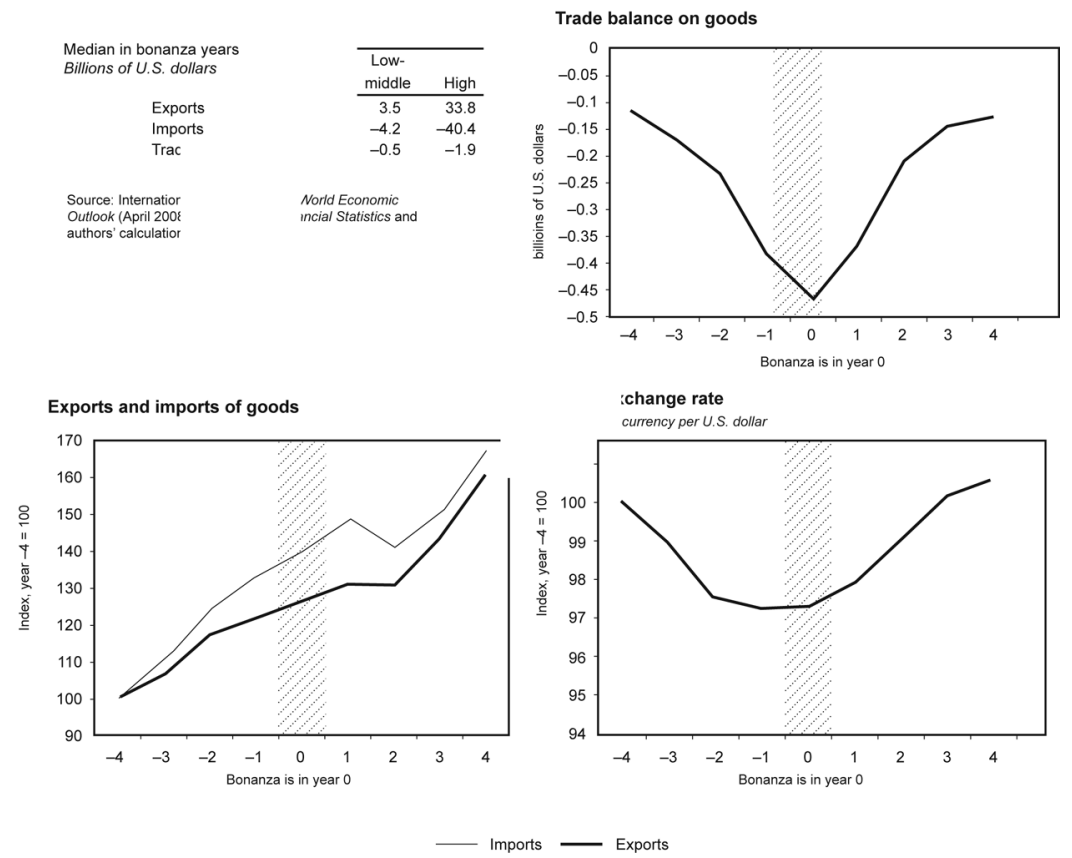

Fig. 14. External indicators and bonanzas, 66 countries, 1960-2007. Sources: International Monetary Fund, World Economic Outlook (April 2008), International Financial Statistics, and authors' calculations. 
are staggering; these policy challenges are discussed in detail and examples provided in Reinhart and Reinhart (1998). Policy responses can mitigate the downside of capital flow bonanzas (recall that the main conclusion from the preceding section is that bonanzas are historically associated with higher odds of a financial crisis) or amplify their more worrisome tendencies. The mismanagement of capital flow bonanza/ commodity price boom episodes (see Cuddington 1989) more often than not has its roots in the authorities' premise that the "good times" are permanent and, as such, can fully support a full-fledged expansion in real fiscal spending. This is the essence of fiscal procyclicality as documented by Gavin and Perotti (1997) and Kaminsky et al. (2004).

Figure 15 presents, in a comparable format, the evolution of real government spending and revenues and the fiscal balance (all indexed to the level 4 years prior to the bonanza). The deeply entrenched pattern of procyclical fiscal behavior by middle- and low-income countries emerges unambiguously from the three panels that make up the figure. Government spending from 2 years prior to the year of the bonanza rises by about $20 \%$ in real terms at a time during which growth is accelerating, as discussed. Despite even faster growth in government revenues (than in expenditures),
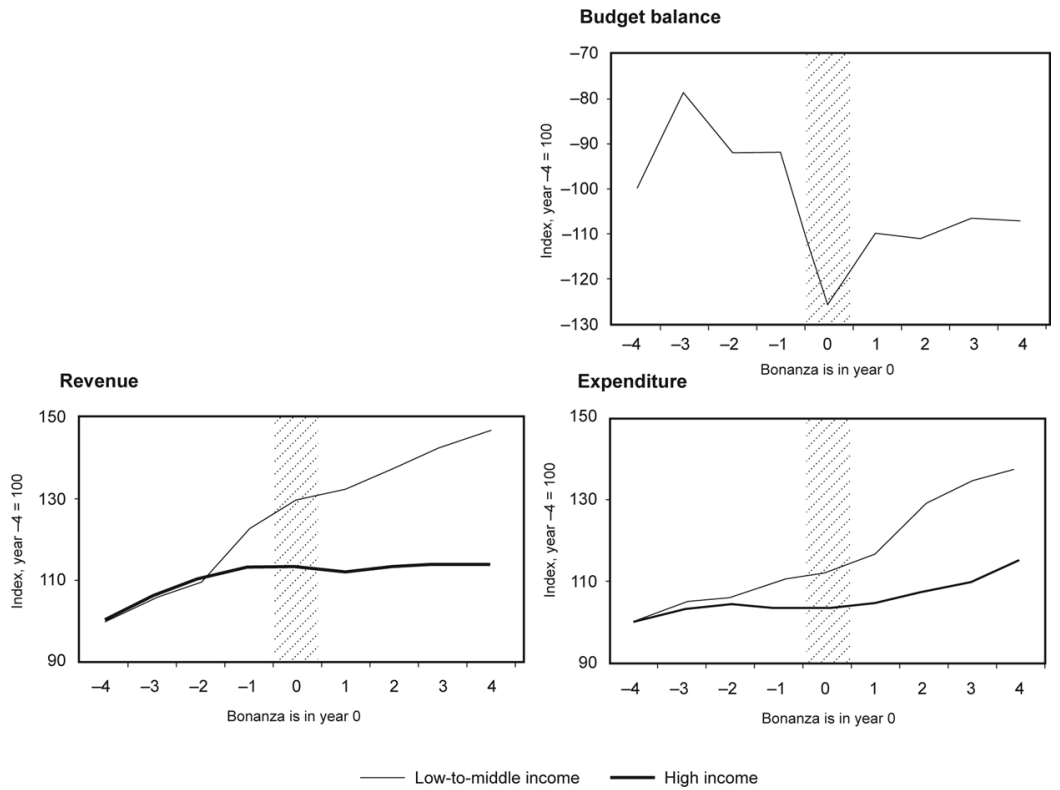

Fig. 15. Fiscal indicators and bonanzas, 66 countries, 1960-2007. Sources: International Monetary Fund, World Economic Outlook (April 2008), International Financial Statistics, Government Financial Statistics, and authors' calculations. 
the fiscal balance deteriorates markedly into the bonanza year. (This deterioration materializes because, while revenues are growing more rapidly, they are doing so from a lower base than expenditures 4 years prior to the bonanza.) The lax expenditure during the boom phase (and the associated deterioration in the fiscal balance) sets the stage for a "nonvoluntary" fiscal tightening when the economic downturn sets in. Hence, as Kaminsky et al. (2004) illustrate, the magnitude of the swing in real fiscal spending during the cycle from boom to bust can be as large as $25-35$ percentage points (as in the case of Uganda and Liberia, respectively). ${ }^{19}$

Kaminsky et al. rank the government's procyclicality propensity by two measures: the correlation between the cyclical component of real GDP and real fiscal spending (if positive, it implies procyclicality) and the amplitude of the swing in real spending (as described). Using these two indicators, we conducted a simple exercise to shed light on the plausible conjecture that the procyclical nature of government spending may help explain why the odds of a financial crisis increase around capital flow bonanzas, as illustrated in the preceding section. On a cross-country basis, we correlated the difference between the con-

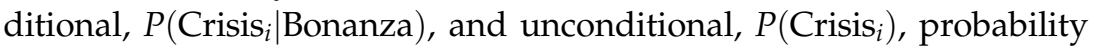
for each of the four types of crises (as shown for selected countries in figs. 4-8) and the two Kaminsky et al. measures of fiscal procyclicality (one at a time). The eight correlations were positive, ranging from 0.25 to 0.46 ; six of the correlations were statistically significant. The results of these preliminary exercises are, thus, consistent with our conjecture about the destabilizing role of fiscal policy around capital flow bonanzas-and possibly more generally.

\section{Asset Markets}

The last indicators we examine around bonanza periods are asset prices, specifically, real equity prices for the 66-country sample and real house prices for a subset of 18 high-income countries for the period 1970-2007. There has been discussion and some anecdotal evidence to suggest that asset prices boom during some famous capital inflow bonanzas (as in Calvo, Izquierdo, and Talvi [2003]). Such a phenomenon appears reasonable, since a capital inflow represents an increased demand (by the rest of the world) for a particular country's assets, which would include equity and real estate. As to asset prices and crises, one cannot read Kindleberger (1989) without drawing a tight link between the two.

Kaminsky and Reinhart (1999) present evidence to suggest that equity price bubbles are systematically present on the eve of banking crises; 
Real equity prices

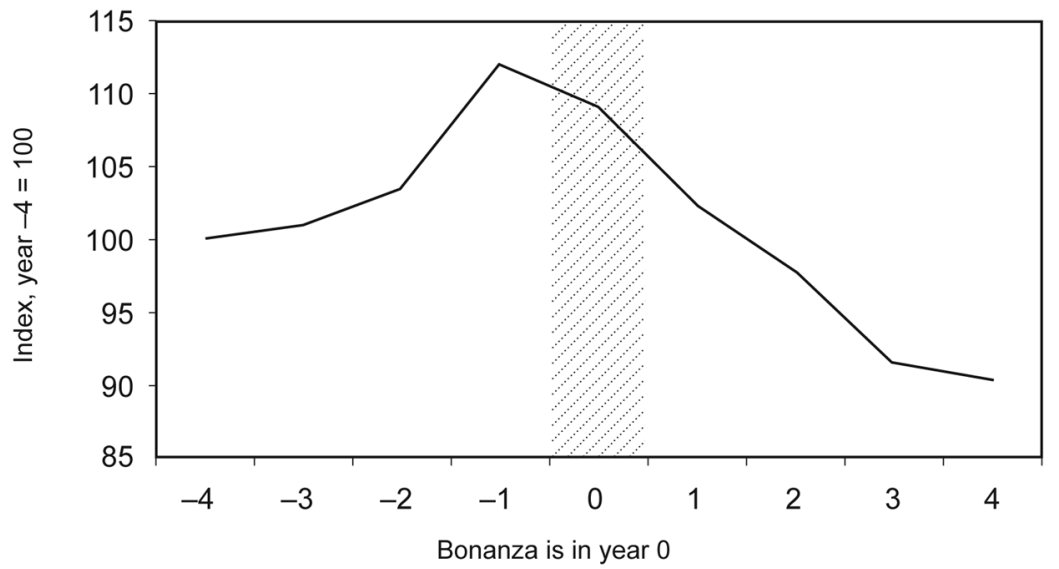

Fig. 16. Equity prices and bonanzas, 66 countries, 1960-2007. Sources: International Monetary Fund, World Economic Outlook (April 2008), International Financial Statistics, and authors' calculations.

indeed, they are a good leading indicator of these. Reinhart and Rogoff (2008a) present evidence that real house prices boomed on the eve of the worst post-World War II banking crises in emerging market economies.

Figures 16 and 17 suggest a three-way link between capital inflow bonanzas, asset price booms, and financial crises. For both asset markets (for equities in fig. 16 and houses in fig. 17), there is a marked rise in inflation-adjusted prices that peaks at the time of the bonanza and is followed by a sustained decline during the 4 years following the bonanza. When the evidence on the higher likelihood of a sovereign default in particular (and other types of financial crises in general), the slowdown in real GDP growth, and the protracted decline in asset values following the capital bonanza are taken together, the swift corrections in the twin deficits (current account and fiscal) observed after the bonanza may likely be a matter of necessity rather than choice.

\section{Conclusion}

Conversations revolving around international financial adjustment sometimes have an aspect similar to the climactic scene in a few Hollywood crime movies in which the villain lures the hero into a hall of mirrors. It is not clear which is the originating action and which is the reflection, so that left can be right, or right left. Invariably, the initial target turns out to be glass. In international finance, one country's current account 


\section{Current account to GDP}

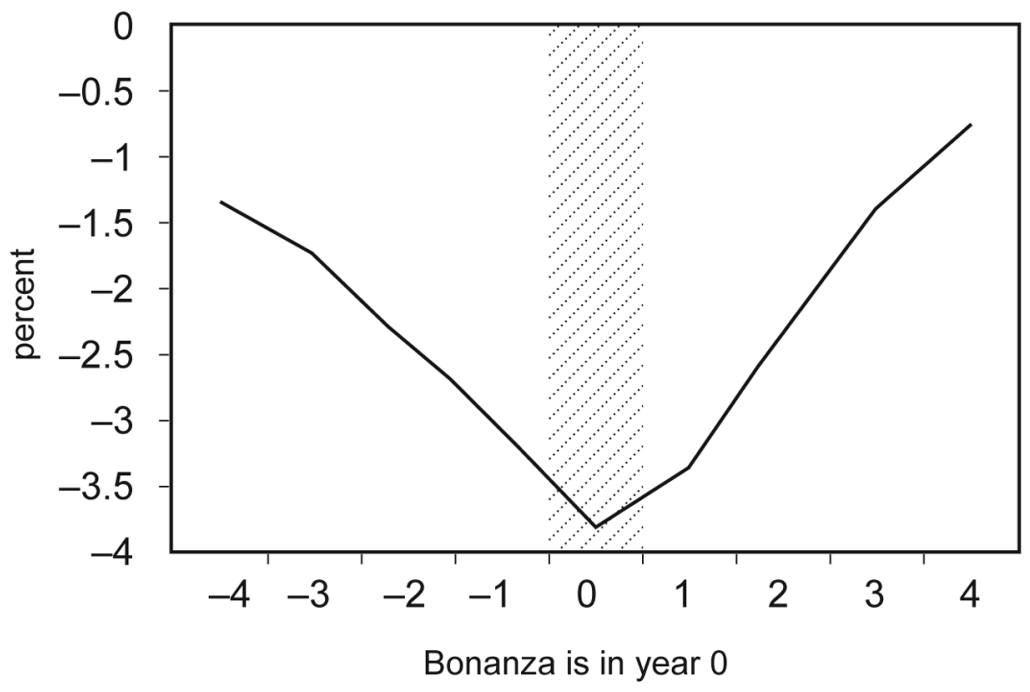

\section{Real house prices}

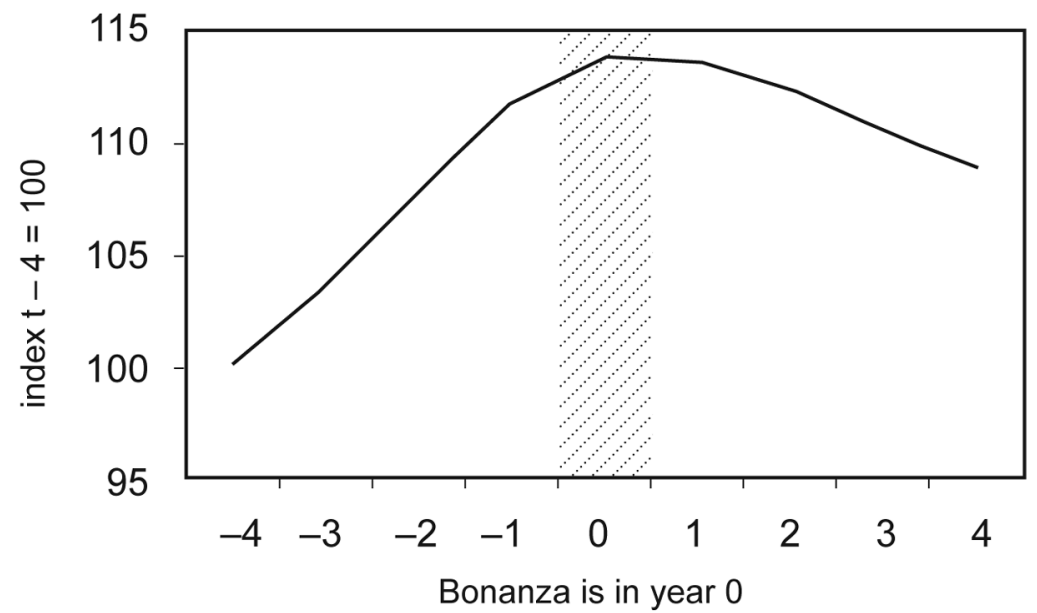

Fig. 17. House prices and bonanzas, 18 advanced countries, 1970-2006. Sources: International Monetary Fund, World Economic Outlook (April 2008), International Financial Statistics, Bank for International Settlements, and authors' calculations. 
surplus can correspond to many countries' deficits, and a surplus is mirrored in a deficit in the capital account. As a consequence, the considerable literature on international adjustment overlaps to a significant degree, even though the studies adopt different selection criteria for what constitutes an event.

We have adopted a back-to-basics approach toward understanding some of the features of episodes of heavy capital inflows that, given double-entry bookkeeping, have usually meant periods of large current account deficits by historical standards. By focusing squarely on the perspective of the recipient of capital inflows (wherever or however poor or wealthy that country may be), our analysis does not extend to issues pertaining to lending countries or the broader and currently popular discussion of global imbalances. Nearly all the areas we have touched on, as to both the causes and consequences of the bonanzas, merit further scrutiny, particularly as relating to the links between asset prices, bubbles, crises, and capital flows.

As to the policy responses to capital inflow bonanzas, our analysis has been silent in all dimensions but one. Namely, we present evidence on the infamously procyclical and destabilizing reaction of fiscal policy (specifically, government spending) to the capital flow bonanza in nearly all but the high-income countries. ${ }^{20}$ The expansionary fiscal policy unfolds against a backdrop of higher growth in output and government revenues associated with the bonanza. It is not unreasonable to conjecture that these government spending practices in "good times" set the stage for a multidecade pattern of serial default.

During the past few years, international interest rates have remained low (by historical standards), and real interest rates have turned negative on a sustained basis for the first time since the late 1970s. Commodity prices have surged. Once again, investors in the financial centers of the world and elsewhere are tripping over themselves in the eternal quest for higher yields in emerging markets and other higher-risk investments. From an emerging market perspective, the external scenario of the past few years can be best characterized as "benign." Yet, as of 2007, 85\% of countries in our core sample have recorded increases in real government expenditures. Perhaps once again authorities view the favorable global environment as permanent. Fully two-thirds of the 181 countries covered in the IMF's latest World Economic Outlook recorded higher inflation in 2007 than in 2006, and an equal share recorded even higher inflation on a year-end basis in 2007 than on a year-average basis-pointing to even higher readings for 2008. If this is what is to be expected in good times, where capital bonanzas are plentiful, it is perhaps time to start rereading Kindleberger. 


\section{Appendix}

Table A1

66 Countries, 1960-2007

\begin{tabular}{llll}
\hline Low Income (8) & \multicolumn{1}{c}{$\begin{array}{c}\text { Middle-Low } \\
\text { Income (20) }\end{array}$} & $\begin{array}{l}\text { Middle-High } \\
\text { Income (16) }\end{array}$ & \multicolumn{1}{c}{$\begin{array}{c}\text { High } \\
\text { Income (22) }\end{array}$} \\
\hline Central African Republic & Algeria & Argentina & Austria \\
Côte d'Ivoire & Angola & Brazil & Australia \\
India & Bolivia & Chile & Belgium \\
Kenya & China & Costa Rica & Canada \\
Myanmar & Colombia & Hungary & Denmark \\
Nigeria & Dominican Republic & Malaysia & Finland \\
Zambia & Ecuador & Mauritius & France \\
Zimbabwe & Egypt & Mexico & Germany \\
& El Salvador & Panama & Greece \\
& Guatemala & Poland & Hong Kong SAR \\
& Honduras & Romania & Italy \\
& Indonesia & Russia & Japan \\
& Morocco & South Africa & Korea \\
& Nicaragua & Turkey & Netherlands \\
& Paraguay & Uruguay & New Zealand \\
& Peru & Venezuela & Norway \\
& Philippines & & Portugal \\
& Sri Lanka & & Singapore \\
& Thailand & & Spain \\
& Tunisia & & Sweden \\
& & United Kingdom \\
& & United States \\
\hline
\end{tabular}

Note: Income classification from the World Bank. Number of countries in each category is shown in parentheses.

Table A2

Country Coverage: 181 Countries, 1980-2007

\begin{tabular}{|c|c|c|c|}
\hline Low Income (50) & $\begin{array}{l}\text { Middle-Low } \\
\text { Income (51) }\end{array}$ & $\begin{array}{l}\text { Middle-High } \\
\text { Income (37) }\end{array}$ & $\begin{array}{c}\text { High } \\
\text { Income (40) }\end{array}$ \\
\hline $\begin{array}{l}\text { Afghanistan, } \\
\text { Republic of }\end{array}$ & Albania & Argentina & Bahamas \\
\hline Bangladesh & Algeria & Belize & Bahrain \\
\hline Benin & Angola & Botswana & Barbados \\
\hline Burkina Faso & Armenia & Brazil & Belgium \\
\hline Burundi & Azerbaijan & Bulgaria & Brunei Darussalam \\
\hline Côte d'Ivoire & Belarus & Chile & Canada \\
\hline Cambodia & Bhutan & Costa Rica & Cyprus \\
\hline $\begin{array}{l}\text { Central African } \\
\text { Republic }\end{array}$ & Bolivia & Croatia & Czech Republic \\
\hline
\end{tabular}


Table A2

Continued

\begin{tabular}{|c|c|c|c|}
\hline Low Income (50) & $\begin{array}{l}\text { Middle-Low } \\
\text { Income (51) }\end{array}$ & $\begin{array}{l}\text { Middle-High } \\
\text { Income (37) }\end{array}$ & $\begin{array}{c}\text { High } \\
\text { Income }(40)\end{array}$ \\
\hline Chad & $\begin{array}{l}\text { Bosnia and } \\
\text { Herzegovina }\end{array}$ & Dominica & Denmark \\
\hline Comoros & Cameroon & Equatorial Guinea & Estonia \\
\hline $\begin{array}{l}\text { Congo, } \\
\text { Democratic } \\
\text { Republic of }\end{array}$ & Cape Verde & Gabon & Finland \\
\hline Eritrea & China & Grenada & France \\
\hline Ethiopia & Colombia & Hungary & Germany \\
\hline Gambia & Congo, Republic of & Kazakhstan & Greece \\
\hline Ghana & Djibouti & Latvia & Hong Kong SAR \\
\hline Guinea & $\begin{array}{l}\text { Dominican } \\
\text { Republic }\end{array}$ & Lebanon & Iceland \\
\hline Guinea-Bissau & Ecuador & Libya & Ireland \\
\hline Haiti & Egypt & Lithuania & Israel \\
\hline India & El Salvador & Malaysia & Italy \\
\hline Kyrgyz Republic & Fiji & Mauritius & Japan \\
\hline $\begin{array}{l}\text { Lao People's } \\
\text { Democratic } \\
\text { Republic }\end{array}$ & Georgia & Mexico & Korea \\
\hline Liberia & Guatemala & $\begin{array}{l}\text { Montenegro, } \\
\text { Republic of }\end{array}$ & Kuwait \\
\hline Madagascar & Guyana & Oman & Luxembourg \\
\hline Malawi & Honduras & Panama & Malta \\
\hline Mali & Indonesia & Poland & Netherlands \\
\hline Mauritania & $\begin{array}{l}\text { Iran, Islamic } \\
\text { Republic of }\end{array}$ & Romania & New Zealand \\
\hline Mongolia & Jamaica & Russia & Norway \\
\hline Mozambique & Jordan & Serbia & Portugal \\
\hline Myanmar & Kenya & Seychelles & Qatar \\
\hline Nepal & Kiribati & Slovak Republic & Saudi Arabia \\
\hline Niger & Lesotho & South Africa & Singapore \\
\hline Nigeria & $\begin{array}{l}\text { Macedonia, } \\
\text { Former Yugoslav } \\
\text { Republic of }\end{array}$ & St. Kitts and Nevis & Slovenia \\
\hline Pakistan & Maldives & St. Lucia & Spain \\
\hline $\begin{array}{l}\text { Papua New } \\
\text { Guinea }\end{array}$ & Moldova & $\begin{array}{l}\text { St. Vincent and } \\
\text { the Grenadines }\end{array}$ & Sweden \\
\hline Rwanda & Morocco & Turkey & Switzerland \\
\hline Senegal & Namibia & Uruguay & $\begin{array}{l}\text { Taiwan Province } \\
\text { of China }\end{array}$ \\
\hline Sierra Leone & Nicaragua & Venezuela & Trinidad and Tobago \\
\hline Solomon Islands & Paraguay & & United Arab Emirates \\
\hline Sudan & Peru & & United Kingdom \\
\hline $\begin{array}{l}\text { São Tomé } \\
\text { and Príncipe }\end{array}$ & Philippines & & United States \\
\hline Tajikistan & Samoa & & \\
\hline
\end{tabular}


Table A2

Continued

\begin{tabular}{llll}
\hline Low Income (50) & \multicolumn{1}{c}{$\begin{array}{c}\text { Middle-Low } \\
\text { Income (51) }\end{array}$} & $\begin{array}{c}\text { Middle-High } \\
\text { Income (37) }\end{array}$ & $\begin{array}{c}\text { High } \\
\text { Income (40) }\end{array}$ \\
\hline Tanzania & Sri Lanka & \\
Timor & Suriname & \\
Togo & Swaziland & \\
Uganda & Syrian Arab Republic & \\
Uzbekistan & Thailand & \\
Vietnam & Tonga & \\
Yemen, Republic of & Tunisia & \\
Zambia & Turkmenistan & \\
Zimbabwe & Ukraine & \\
& Vanuatu & \\
\hline
\end{tabular}

\section{Table A3}

List of Variables

\begin{tabular}{ll}
\hline Variable & \\
\hline GDP, IMF World Economic Outlook: & Billions \\
$\quad$ Nominal GDP & \\
Real GDP & Billions of U.S. dollars \\
External accounts, IMF World Economic Outlook: & \\
$\quad$ Total capital flows, net & \\
Current account balance & \\
Financial account balance & \\
Trade balance & \\
Foreign reserves & \\
Imports of goods and services & \\
Exports of goods and services & \\
Prices: & \\
Consumer price index, IMF World Economic Outlook & Indices \\
Inflation & Percent \\
Equity prices, IMF International Financial Statistics & Indices \\
House prices, Bank for International Settlements & Indices \\
Exchange rate, International Financial Statistics & National currency per U.S. dollar \\
Fiscal and national accounts, IMF World Economic & \\
Outlook and Government Financial Statistics: & Billions of national currency \\
Central government balance & \\
Central government expenditure & \\
Central government revenue & \\
Other variables: & \\
Crises indicators, Reinhart and Rogoff (2008b) & Indices \\
Commodity prices, Boughton (1991) & Index \\
and IMF World Economic Outlook & \\
Short-term interest rates, OECD and IMF & \\
$\quad$ International Financial Statistics & \\
\hline
\end{tabular}


Table A4

Dates of Capital Flow Bonanzas and External Debt Crises: Extended Sample, 1980-2007

\begin{tabular}{|c|c|c|}
\hline Country & Years of Bonanzas & $\begin{array}{l}\text { Years of External } \\
\text { Default }\end{array}$ \\
\hline \multicolumn{3}{|l|}{ High income, OECD: } \\
\hline Australia & 1986, 1989, 2004-5, 2007 & \\
\hline Austria & 1980-81, 1995-97, 1999 & \\
\hline Belgium & $1980-84$ & \\
\hline Canada & $1981,1989-93$ & \\
\hline Denmark & $1981-82,1984-87$ & \\
\hline Finland & $1982-83,2005-7$ & \\
\hline France & $1980,1988-92$ & \\
\hline Germany & $1980,1991,1994-95,1999-2000$ & \\
\hline Greece & $1983,1985,2000,2006-7$ & \\
\hline Iceland & $1982,2000,2004-7$ & \\
\hline Ireland & 1980-84, 2007 & \\
\hline Italy & $1980-82,1991-92$ & \\
\hline Korea & $1980-83,1991,1996$ & $1998^{\mathrm{a}}$ \\
\hline New Zealand & $1982,1984-85,2005-7$ & \\
\hline Norway & $1986-89,1998$ & \\
\hline Portugal & 1981-82, 2000-2001, 2005 & \\
\hline Spain & $2000,2004-7$ & \\
\hline Sweden & $1980-82,1990-92$ & \\
\hline United Kingdom & $1988-90,2005-7$ & \\
\hline United States & $2002-7$ & \\
\hline \multicolumn{3}{|c|}{ High income, non-OECD: } \\
\hline Antigua and Barbuda & $1981-82,1986-89$ & 1996-2006 \\
\hline Bahamas & $1997-98,2005-7$ & \\
\hline Bahrain & 1987, 1989, 1991-93, 1998 & \\
\hline Barbados & $1981,2004-7$ & \\
\hline Cyprus & $1980,1983-84,1991-92$ & \\
\hline Czech Republic & $1996-97,2001-4$ & \\
\hline Estonia & $2004,2006-7$ & \\
\hline Georgia & $1994-95,2007$ & \\
\hline Hong Kong, SAR & 1980-81, 1994-97 & \\
\hline Israel & $1981-84,1995-96$ & \\
\hline Kuwait & 1993, 1995-96, 1998 & \\
\hline Malta & 1995-96, 2000 & \\
\hline Qatar & $1992,2004-7$ & \\
\hline Saudi Arabia & 1983-84, 1986, 1991-93 & \\
\hline Singapore & $1980-84,1987$ & \\
\hline Slovenia & $1999,2006-7$ & \\
\hline Trinidad and Tobago & $1982-84,1986,1997-98$ & $1988-89$ \\
\hline \multicolumn{3}{|l|}{ Middle-high income: } \\
\hline Argentina & 1982, 1987, 1994, 1997-99 & $1982-93,2004-5$ \\
\hline Belize & $2000-2005$ & \\
\hline Botswana & 1980-84, 1990 & \\
\hline Brazil & 1980-83, 1999, 2001 & $1983-84$ \\
\hline Bulgaria & $1990-93,2005-7$ & 1990-94 \\
\hline Chile & $1980-82,1984-86$ & $1983-90$ \\
\hline Costa Rica & $1980-83,1989-90$ & 1981-90 \\
\hline
\end{tabular}


Table A4

Continued

\begin{tabular}{|c|c|c|}
\hline Country & Years of Bonanzas & $\begin{array}{l}\text { Years of External } \\
\text { Default }\end{array}$ \\
\hline Croatia & 1997, 2002, 2007 & $1992-96$ \\
\hline Dominica & 1980-81, 1989-90, 2005 & $2003-5$ \\
\hline Equatorial Guinea & 1980-82, 1995-96, 1998 & \\
\hline Gabon & $1986-89,1992,1998$ & 1986-94, 1999-2004 \\
\hline Grenada & $2001-3,2006-7$ & \\
\hline Hungary & $\begin{array}{r}1986-87,1993-94 \\
1998-99,2003-4\end{array}$ & \\
\hline Latvia & $2004,2006-7$ & \\
\hline Lebanon & $1983,1990-92,1997-98$ & \\
\hline Malaysia & 1981-83, 1991, 1994-95 & \\
\hline Mauritius & $1980-82,2006-7$ & \\
\hline Mexico & $198--81,1991-94$ & $1982-90,1995^{\mathrm{a}}$ \\
\hline Oman & $1986,1992-95,1998$ & \\
\hline Panama & 1980-82, 1997-98, 2007 & 1983-96 \\
\hline Poland & $1980-81,1985-89$ & 1981-94 \\
\hline Romania & $1992,2004-7$ & $1981-83,1986$ \\
\hline Russia & 1992,1997 & \\
\hline Serbia & 2007 & 1992-2004 \\
\hline Seychelles & 1982, 1999, 2001, 2005, 2007 & 2000-2002 \\
\hline Slovak Republic & 1996-98 & \\
\hline South Africa & $1981-82,2005-7$ & $1985-87,1989,1993$ \\
\hline St. Kitts and Nevis & $1989,2003-3,2007$ & \\
\hline St. Lucia & $1980,1983,2003,2006-7$ & \\
\hline $\begin{array}{l}\text { St. Vincent and } \\
\text { the Grenadines }\end{array}$ & $1997-98,2004,2006-7$ & \\
\hline Turkey & $1980,2000,2004-7$ & 1982 \\
\hline Uruguay & $1980-84,2001$ & \\
\hline Venezuela & $1982,1987-88,1992-93,1998$ & $\begin{array}{l}1983-88,1990 \\
1995-97,2004-5\end{array}$ \\
\hline \multicolumn{3}{|l|}{ Middle-low income: } \\
\hline Albania & 1991-92, 1997, 2002, 2007 & 1991-95 \\
\hline Algeria & $\begin{array}{c}1969,1973,1975-79,1986 \\
1988-89,1994-95,1998\end{array}$ & $1991-96$ \\
\hline Angola & 1982, 1995, 1997-99, 2001 & 1985-2003 \\
\hline Armenia & $1992,1996-98$ & \\
\hline Azerbaijan & $1996,1998,2003-4$ & \\
\hline Bhutan & $1982-87$ & \\
\hline Bolivia & 1981, 1985-87, 1993, 1998 & $1980-84,1986-97$ \\
\hline Bosnia and Herzegovina & 2003,2005 & 1992-97 \\
\hline Cameroon & $1980-81,1987-88,1993,2002$ & $1987-2003$ \\
\hline Cape Verde & $1980-81,1999,2003-4$ & $1981-96$ \\
\hline China & $1985-86,1988-89,1993$ & \\
\hline Colombia & $1982-83,1995,1997-98$ & \\
\hline $\begin{array}{l}\text { Congo, Republic of } \\
\text { Dijibouti }\end{array}$ & $\begin{array}{l}1994-96,1998-99,2007 \\
2000,2006-7\end{array}$ & 1983-2007 \\
\hline Dominican Republic & $1980-82,1987$ & 1982-94, 2005 (contin \\
\hline
\end{tabular}


Table A4

Continued

\begin{tabular}{|c|c|c|}
\hline Country & Years of Bonanzas & $\begin{array}{c}\text { Years of External } \\
\text { Default }\end{array}$ \\
\hline Ecuador & $\begin{array}{l}\text { 1981-82, 1987, 1989, } \\
\text { 1991, } 1998\end{array}$ & $1982-95,1999-2000$ \\
\hline Egypt & $1981-85,1998$ & \\
\hline El Salvador & 1989, 1990, 2003, 2005, 2007 & \\
\hline Fiji & 1981, 2004-7 & \\
\hline Guatemala & $\begin{array}{l}\text { 1981, 1987, 1992-93, 1994, } \\
\text { 1999, } 2001\end{array}$ & 1986, 1989 \\
\hline Guyana & $1980-83,1985-86$ & $1982-86$ \\
\hline Honduras & 1980-81, 1984, 2003-4, 2007 & 1981-2007 \\
\hline Indonesia & $1982-83,1986-87,1991,1995$ & 1998-2001, 2002 \\
\hline Iran, Islamic Republic of & $1980-81,1986,1991-93$ & 1980-95 \\
\hline Jamaica & $1981-82,1985,2007$ & $1981-85,1987-93$ \\
\hline Jordan & $1990-92,2005,2007$ & 1989-93 \\
\hline Kiribati & $1992,1996,2005-7$ & \\
\hline Lesotho & $1991-93,1996-98$ & \\
\hline Macedonia & $1994,1997-98,2002$ & 1983-99 \\
\hline Maldives & $1980,1993,2005-7$ & \\
\hline Moldova & $1993,1997-98,2006$ & 1998,2002 \\
\hline Morocco & $1981,1983-87$ & $1983,1986-90$ \\
\hline Nicaragua & $1988,1990-94$ & \\
\hline Paraguay & 1980-82, 1986-87, 1996 & $1986-92,2003-4$ \\
\hline Peru & 1981-83, 1993, 1995, 1998 & 1980, 1983-97 \\
\hline Philippines & $\begin{array}{l}1980,1982-83,1990 \\
1993,1997\end{array}$ & 1983-92 \\
\hline Samoa & 1980-81, 1991-93, 2003 & \\
\hline Sri Lanka & $1979-84,1986,1988$ & $1981-83$ \\
\hline Suriname & $\begin{array}{l}\text { 1983, 1991, 1998-99, } \\
\text { 2001, } 2003\end{array}$ & \\
\hline Swaziland & 1980-85 & \\
\hline Syrian Arab Republic & $1980,1983,1994,2006-7$ & \\
\hline Thailand & $1981-83,1990-91,1995-96$ & \\
\hline Tonga & 1990-91, 1994-95, 1998 & \\
\hline Tunisia & 1981-84, 1986, 1993 & 1980-82 \\
\hline Turkmenistan & $1995,1997-99$ & \\
\hline Ukraine & $1994-95,2007$ & 1998-2000 \\
\hline Vanuatu & $2002-3,2005-7$ & \\
\hline \multicolumn{3}{|l|}{ Low income: } \\
\hline Benin & $1981-83,1988,2002-3$ & \\
\hline Burkina Faso & 1999-2001, 2004-5 & 1987-96 \\
\hline Burundi & $1982-83,1987,1990,2006-7$ & \\
\hline Cambodia & $1988-89,1996,1998$ & \\
\hline Central African Republic & $1980,1982-84,1992-95$ & $1981,1983-2007$ \\
\hline Chad & $1986,2000-2004$ & \\
\hline Comoros & 1984-85, 1987, 1994, 1997 & \\
\hline $\begin{array}{l}\text { Congo, Democratic } \\
\text { Republic of }\end{array}$ & 1987, 1989, 1991-92, 2005 & 1980-2007 \\
\hline Côte d'Ivoire & $1980,1988-92$ & $\begin{array}{r}\text { 1983-98, 2000-2007 } \\
\text { (continued }\end{array}$ \\
\hline
\end{tabular}


Table A4

Continued

\begin{tabular}{|c|c|c|}
\hline Country & Years of Bonanzas & $\begin{array}{c}\text { Years of External } \\
\text { Default }\end{array}$ \\
\hline Ethiopia & $1999,2002,2005-7$ & 1991-99 \\
\hline Gambia & 1980-81, 1996, 2005 & $1986-90$ \\
\hline Ghana & $1993,1997,1999,2006-7$ & 1968, 1970, 1974, 1987 \\
\hline Guinea & 1988-90, 1996, 2007 & 1985-88, 1991-98 \\
\hline Haiti & $1980-81,1990-93$ & 1982-99 \\
\hline India & $1984,1987-90$ & \\
\hline Kenya & 1980-81, 1987, 1989, 1995 & 1994-98, 2000 \\
\hline $\begin{array}{l}\text { Lao People's } \\
\text { Democratic Republic }\end{array}$ & $1988-89,2004-5,2007$ & \\
\hline Madagascar & 1980-81, 1990, 2005, 2007 & 1981-2002 \\
\hline Malawi & $\begin{array}{l}\text { 1980, 1992, 1994, 1997, } \\
\text { 2002, } 2005\end{array}$ & 1982,1988 \\
\hline Mali & 1980, 1996, 1999-2001, 2004 & \\
\hline Mauritania & 1980-83, 2004-5 & $1992-96$ \\
\hline Mongolia & $1998,2002-3$ & \\
\hline Mozambique & $1987-89,1993-95$ & 1983-92 \\
\hline Myanmar & 1981-82, 1990-92, 1998 & $2002-7$ \\
\hline Nepal & 1982-84, 1989-91 & \\
\hline Niger & $1980-82,2005-6$ & \\
\hline Nigeria & 1981-83, 1986, 1993, 2002 & 1987-94, 2004-5 \\
\hline Pakistan & $1993,1996-97,2007$ & $1981,1998-99$ \\
\hline Papua New Guinea & 1980-84, 1997 & \\
\hline Rwanda & 1991-93, 1997-98 & \\
\hline São Tomé and Príncipe & $1982,1991-92,2007$ & 1987-94 \\
\hline Senegal & 1980-84 & $1981-85,1990,1992-96$ \\
\hline Sierra Leone & 1980-82, 1990-91, 1996 & 1983-84, 1986-96 \\
\hline Solomon Islands & $1985,1991,2005-7$ & \\
\hline Sudan & $1981-82,1992-95$ & 1980-2007 \\
\hline Tanzania & 1994-95, 1998-99 & $\begin{array}{l}\text { 1980, 1982-84, 1988, } \\
\text { 1991-97 }\end{array}$ \\
\hline Togo & $1980,1982-83,1987$ & 1980-93 \\
\hline Uganda & 1991, 1993, 1998-2001 & $1981,1985-93$ \\
\hline Vietnam & 1993-96, 2007 & 1985-98 \\
\hline Zambia & $1981-82,1998,2000-2001$ & 1983-94 \\
\hline Zimbabwe & $1981-82,1992,2004-5$ & 2000-2007 \\
\hline
\end{tabular}

Note: The dates shown are those picked up by the algorithm described in the preceding section. Consecutive years (e.g., Greece 2000, 2001) are treated as a single episode.

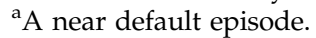




\section{Comparing definitions of Capital Flow Bonanzas}

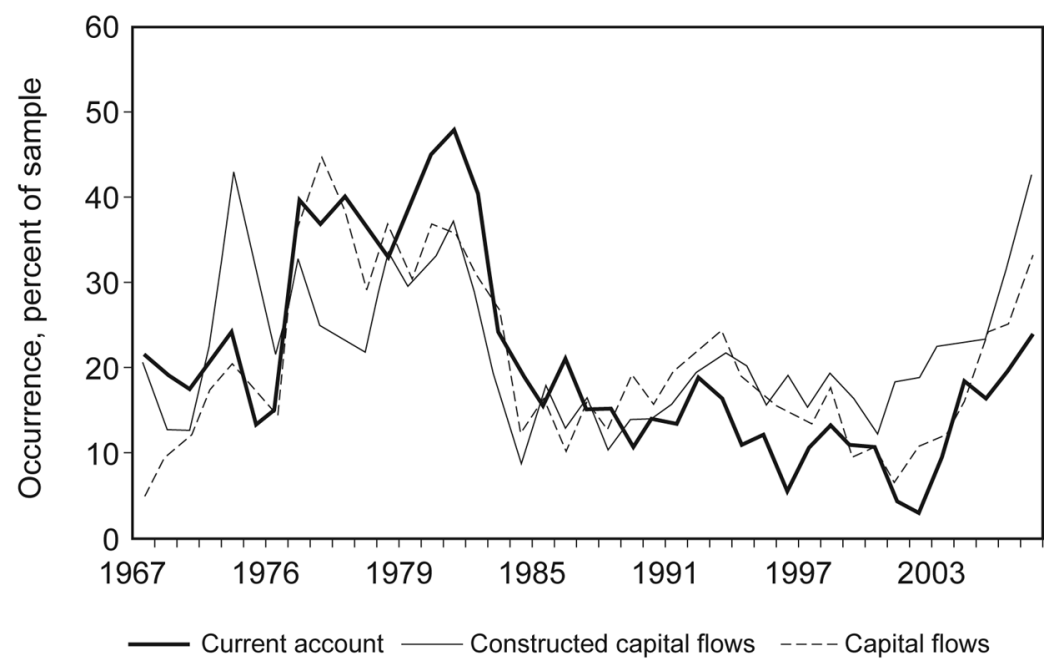

Fig. A1. Comparing definitions of capital flow bonanzas, 66 countries, 1960-2007. Sources: Authors' calculations and sources listed in app. table A3.

\section{Endnotes}

This paper was prepared for the NBER's 2008 International Seminar on Macroeconomics, Ljubljana, Slovenia. It was presented there and at the 15th Congress of the International Economic Association in Istanbul, Turkey. The authors wish to thank Jeff Frankel, Francisco Giavazzi, Alejandro Izquierdo, Frank Warnock, and other participants for helpful comments. Meagan Berry, Adam Paul, and Anna Stumpf provided excellent research assistance.

1. Gourinchas, Landerretche, and Valdes (2001) perform a similar exercise to assess which credit booms end in crises and credit crunches and which do not. Edwards (2004) is particularly careful in trying to consider both abrupt reversals and more gradual adjustment.

2. We would also like to thank Gian Maria Milesi-Ferretti for pointing out that the financial account figures have to be interpreted with care during years in which there is debt forgiveness, which show up as large debt repayments (i.e., capital outflows).

3. We also impose a nonnegativity constraint, so countries that are capital exporters throughout the sample never record a bonanza.

4. The interested reader is referred to app. fig. A1, which provides a comparison among three definitions of bonanza episodes: using the current account, the financial account, and capital flows.

5 . The income group classification is that provided by the World Bank.

6. For example, Sarno and Taylor (1999), using standard time-series techniques, decompose the various components of international capital flows into their permanent and transitory components.

7. Lucas (1990) suggested that human capital differentials might account for this "paradox," whereas Reinhart and Rogoff (2004) and Alfaro, Kalemli-Ozcan, and Volosovych (2008) point to the high incidence of sovereign default and weak institutions, respectively.

8. The link between capital flow bonanzas and debt crises will be the focus of Sec. IV. 
9. Discussions of the earlier wave of capital to central and eastern Europe and the former Soviet Union include Claessens, Oks, and Polastri (1998) and Lankes and Stern (1998); the more recent experience is covered in Lane and Milesi-Ferretti (2007).

10. It is important to note that the middle-income group comprises middle-low and middle-high income (the latter constitutes the largest single group), so our analysis bears on many developing countries beyond the largest emerging markets.

11. See Fernandez-Arias and Montiel (1996) for a survey of a literature that flourished in the early $1990 \mathrm{~s}$.

12. As is conventionally done, the nominal commodity price index is deflated by an index of the price of manufactures (see, e.g., Boughton 1991).

13. The missing two are Japan and the Netherlands, which are creditor countries.

14. There are, however, many instances in which the now-advanced economies defaulted in their earlier incarnations; see Reinhart and Rogoff (2008b) for a full chronology of these episodes.

15. It is important to reiterate that the incidence of sovereign default during the period in question owes to emerging markets.

16. On the basis of the historical track record, it is plausible to expect a higher chance of a sovereign default after a bonanza even in cases in which government debt is not increasing. The reason is that the government sooner or later has usually ended up guaranteeing private-sector debts.

17. See Reinhart and Reinhart (1998) and the references cited therein for a discussion of the stylized facts.

18. See Reinhart and Reinhart (2008) for evidence of fear of floating or, in the recent context, fear of an appreciation.

19. To be clear, the amplitude of the swing is calculated as the percentage growth in real government spending during an expansion minus the growth in government spending in downturns. In the case of an extremely procyclical government, real spending would grow during good times (as shown in fig. 15), perhaps by $15 \%$, and in downturns it would contract by about $10 \%$. Thus the amplitude of the swing during the business cycle would be $25 \%$.

20. It is important to recall that there is a positive association between the degree of fiscal procyclicality and the incremental odds of a financial crisis around capital flow bonanzas.

\section{References}

Alfaro, Laura, Sebnem Kalemli-Ozcan, and Vadym Volosovych. 2008. "Why Doesn't Capital Flow from Rich to Poor Countries? An Empirical Investigation." Review of Economics and Statistics 90 (May): 347-68.

Bastourre, Diego, Jorge Carrera, and Javier Ibarlucia. 2008. "What Is Driving Reserve Accumulation? A Dynamic Panel Approach." Working paper (March), Central Bank of Argentina, Buenos Aires.

Bosworth, Barry P. 1993. Saving and Investment in a Global Economy. Washington, DC: Brookings Institution.

Boughton, James. 1991. "Commodity and Manufactures Prices in the Long Run." Working Paper no. 91/47 (May), International Monetary Fund, Washington, DC.

Calvo, Guillermo A. 1998. "Capital Flows and Capital-Market Crises: The Simple Economics of Sudden Stops." Journal of Applied Economics 1, no. 1:35-54.

$\rightarrow$ Calvo, Guillermo A., Alejandro Izquierdo, and Rudy Loo-Kung. 2006. "Relative Price Volatility under Sudden Stops: The Relevance of Balance Sheet Effects." Journal of International Economics 69 (June): 231-54.

Calvo, Guillermo A., Alejandro Izquierdo, and L. F. Mejía. 2004. "On the Empirics of Sudden Stops: The Relevance of Balance Sheet Effects." Working Paper no. 10520, NBER, Cambridge, MA. 
Calvo, Guillermo A., Alejandro Izquierdo, and Ernesto Talvi. 2003. "Sudden Stops, the Real Exchange Rate, and Fiscal Sustainability: Argentina's Lessons." Working paper, NBER, Cambridge, MA.

$\rightarrow$ Calvo, Guillermo A., Leonardo Leiderman, and Carmen M. Reinhart. 1993. "Capital Inflows and Real Exchange Rate Appreciation in Latin America: The Role of External Factors." IMF Staff Papers 40 (March): 108-51.

Calvo, Guillermo A., and Ernesto Talvi. 2005. "Sudden Stop, Financial Factors and Economic Collapse in Latin America: Learning from Argentina and Chile." Working Paper no. 11153 (February), NBER, Cambridge, MA.

Carroll, Christopher, and Olivier Jeanne. 2008. "A Tractable Model of Precautionary Reserves or Net Foreign Assets." Manuscript (May), Johns Hopkins University.

$\rightarrow$ Chuhan, Punam, Stijn Claessens, and Nlandu Mamingi. 1998. "Equity and Bond Flows to Asia and Latin America: The Role of Global and Country Factors." Journal of Development Economics 55:439-63.

Claessens, Stijn, Daniel Oks, and Rossana Polastri. 1998. "Capital Flows to Central and Eastern Europe and Former Soviet Union." Policy Research Working Paper no. 1976 (November), World Bank, Washington, DC.

$\rightarrow$ Cuddington, John. 1989. "Commodity Export Booms in Developing Countries." World Bank Research Observer 4:143-65.

$\rightarrow$ Diaz-Alejandro, Carlos. 1985. "Good-Bye Financial Repression, Hello Financial Crash." Journal of Development Economics 19 (February): 1-24.

$\rightarrow$ Diebold, Francis X., and Glenn D. Rudebusch. 1989. "Measuring Business Cycles: A Modern Perspective." Review of Economics and Statistics 78, no. 1:67-77.

Dooley, Michael, Eduardo Fernandez-Arias, and Kenneth Kletzer. 1996. "Recent Private Capital Inflows to Developing Countries: Is the Debt Crisis History?" World Bank Economic Review 10 (January): 27-49.

Edwards, Sebastian. 2004. "Thirty Years of Current Account Imbalances, Current Account Reversals, and Sudden Stops." IMF Staff Papers 51:1-50.

2005. "The End of Large Current Account Deficits, 1970-2002: Are There Lessons for the United States?" In The Greenspan Era: Lessons for the Future, 205-68. Kansas City: Federal Reserve Bank of Kansas City.

_. 2007. "Capital Controls, Sudden Stops and Current Account Reversals." In Capital Controls and Capital Flows in Emerging Economies: Policies, Practices, and Consequences, ed. Sebastian Edwards, 73-113. Chicago: University of Chicago Press (for NBER).

Eichengreen, Barry, and Muge Adalet. 2005. "Current Account Reversals: Always a Problem?" Working Paper no. 11634 (September), NBER, Cambridge, MA.

Federal Reserve Bank of Kansas City. 1985. The U.S. Dollar-Recent Developments, Outlook, and Policy Options. Kansas City: Federal Reserve Bank of Kansas City.

Fernandez-Arias, Eduardo, and Peter J. Montiel. 1996. “The Surge in Capital Inflows to Developing Countries: An Analytical Overview." World Bank Economic Review 10, no. 1:51-77.

Frankel, Jeffrey. 2006. "The Effect of Monetary Policy on Real Commodity Prices." In Asset Prices and Monetary Policy, ed. John Campbell. Chicago: University of Chicago Press.

—. 2007. "Getting Carried Away: How the Carry Trade and Its Potential Unwinding Can Explain Movements in International Financial Markets." Manuscript (November), Harvard University.

_ 2008a. "An Explanation for Soaring Commodity Prices." VoxEU (March 25), http:/ / www.voxeu.org/index.php?q=node/1002. 
2008b. "Monetary Policy and Commodity Prices." VoxEU (May 29), http://www.voxeu.org/index.php?q=node/1178.

$\rightarrow$ Frankel, Jeffrey A., and Andrew K. Rose. 1996. "Currency Crashes in Emerging Markets: An Empirical Treatment." Journal of International Economics 41 (November): 351-68.

Freund, Caroline, and Frank Warnock. 2005. "Current Account Deficits in Industrial Countries: The Bigger They Are the Harder They Fall." Working paper, NBER, Cambridge, MA.

$\rightarrow$ Gavin, Michael, and Roberto Perotti. 1997. "Fiscal Policy in Latin America." NBER Macroeconomics Annual 1997:11-61.

$\rightarrow$ Goldfajn, Ilan, and Rodrigo Valdes. 1999. "The Aftermath of Appreciations." Quarterly Journal of Economics 116 (February): 229-62.

Gourinchas, Pierre Olivier, Oscar Landerretche, and Rodrigo Valdes. 2001. "Lending Booms: Latin America and the World." Working Paper no. 8249 (April), NBER, Cambridge, MA.

$\rightarrow$ Kaminsky, Graciela L., and Carmen M. Reinhart. 1999. "The Twin Crises: The Causes of Banking and Balance-of-Payments Problems." American Economic Review 89, no. 3:473-500.

Kaminsky, Graciela L., Carmen M. Reinhart, and Carlos A.Végh. 2004. "When It Rains, It Pours: Procyclical Capital Flows and Policies." NBER Macroeconomics Annual 2004:11-53.

Kindleberger, Charles P. 1989. Manias, Panics and Crashes: A History of Financial Crises. New York: Basic Books.

$\rightarrow$ Lane, Philip, and Gian Maria Milesi-Ferretti. 2007. "Capital Flows to Central and Eastern Europe." Emerging Markets Review 8, no. 2:106-23.

Lankes, Hans Peter, and Nicholas Stern. 1998. "Capital Flows to Eastern Europe and the Former Soviet Union." Working paper (May), European Bank for Reconstruction and Development, London. http:/ /www.eib.org/attachments/ efs/eibpapers_1998_v03_n02/eibpapers_1998_v03_n02_a06_en.pdf.

$\rightarrow$ Lucas, Robert. 1990. "Why Doesn't Capital Flow from Rich to Poor Countries?" American Economic Review Papers and Proceedings 80 (May): 92-96.

Mendoza, Enrique G., and Marco E. Terrones. 2008. "An Anatomy of Credit Booms: Evidence from Macro Aggregates and Micro Data." Working Paper no. 14049 (May), NBER, Cambridge, MA, http://www.nber.org/papers/ w14049.

Milesi-Ferretti, Gian Maria, and Assaf Razin. 2000. "Current Account Reversals and Currency Crises: Empirical Regularities." In Currency Crises, ed. Paul Krugman. Chicago: University of Chicago Press.

Reinhart, Carmen M., and Vincent R. Reinhart. 1998. "Some Lessons for Policymakers Who Deal with the Mixed Blessing of Capital Inflows." In Capital Flows and Financial Crises, ed. Miles Kahler, 93-127. Ithaca, NY: Cornell University Press.

—_. 2008. "Capital Inflows and Reserve Accumulation: The Recent Evidence." Working Paper no. 13842 (March), NBER, Cambridge, MA.

$\rightarrow$ Reinhart, Carmen M., and Kenneth S. Rogoff. 2004. "Serial Default and the 'Paradox' of Rich-to-Poor Capital Flows." American Economic Review Papers and Proceedings 94 (May): 53-58.

$\rightarrow$ - 2008a. "Is the 2007 U.S. Subprime Crisis So Different? An International Historical Comparison." American Economic Review Papers and Proceedings 98 (May): 339-44. 
2008b. "This Time Is Different: A Panoramic View of Eight Centuries of Financial Crises." Working Paper no. 13882 (March), NBER, Cambridge, MA.

$\rightarrow$ Sarno, Lucio, and Mark Taylor. 1999. "Moral Hazard, Asset Price Bubbles, Capital Flows, and the East Asian Crisis: The First Tests." Journal of International Money and Finance 18, no. 4:637-57.

World Bank. 1997. The Road to Financial Integration: Private Capital Flows to Developing Countries. Washington, DC: World Bank. 